\title{
HIGH-RANKING MILITARY OFFICERS: SEPTIMIUS SEVERUS VERSUS GALLIENUS
}

Discussed so far have been changes in power and status of the emperors, the senatorial elite and high equestrians. This chapter examines the military officers, among whom both senators and equestrians played a role. To illustrate the developments in the power and status of military officers during the third century, two cases will be analyzed and compared: the set of high-ranking military officers under Septimius Severus and those operating under Gallienus.

Admittedly, confining oneself to test cases can be tricky, since this could paint too fragmentary a picture. There are, however, several reasons why such an approach is justified. First of all, the overwhelming number of military events in the third century combined with the gradually declining quantity and quality of the evidence precludes mapping out the positions of all third-century military officers. A thorough study of these two cases, separated by about sixty years, will probably create a view of equal, or even better, standing. Second, these cases are both relatively well documented and they correspond in that both at the beginning of Severus' reign and during most of the rule of Gallienus, the Empire experienced crisis, a situation which displays common structures most clearly. ${ }^{1}$ Apart from these parallels which allow for comparison, there are also distinctions which indicate changes and developments in the composition, power and status of the Empire's high-ranking military officers over the course of the third century. Yet the divergent nature and quality of the source material of the two cases, prevents two precisely parallel discussions. The evidence on Septimius Severus' generals offers us the opportunity to draw conclusions about the individuals in the offices. For Gallienus' military officers, however, the evidence is more fragmentary. Nevertheless, it suffices to determine a frame, in which the individual generals fit, and to deduce patterns and draw conclusions.

${ }^{1}$ Cf. Flaig (1997), 20: 'Aber der Ernstfall ist die Probe darauf, welche politischen Beziehungen wirken und welche nicht.' 
An analysis and comparison of these cases will reveal not only a change in the character of the era, but also changes in the social rank of military officers and the declining value of senatorial rank in military contexts. Furthermore, it shows some strategic arrangements of the emperors to secure their power and to prevent the military from becoming a threat. Before we can proceed to an analysis, however, a chronological overview, which will discuss the high-ranking officers who emerge from the literary and epigraphic evidence, is indispensable.

\subsection{Septimius Severus and His Military Officers}

Severus' Initial Support-The Expeditio Urbica (193)

Table 4.1. Severus' supporters in 193

\begin{tabular}{ll} 
Name & Position \\
\hline Clodius Albinus & Legatus Aug pr pr Britanniae \\
Fabius Cilo & Consul suffectus \\
Iulius Avitus Alexianus & Procurator ad annonam Ostiis \\
Iulius Laetus & Commander of the praecursores \\
Iulius Septimius Castinus & Tribunus militum legionis I Adiutricis (Pannonia \\
& Sup.) item V Macedonicae (Moesia Inf.) \\
Marius Maximus & Legatus legionis I Italicae (Moesia Inf.) \\
Septimius Geta & Legatus Aug pr pr Moesiae Inferioris \\
Valerius Valerianus & Praepositus vexillationis \\
\hline
\end{tabular}

In 193, Septimius Severus, governor of Pannonia Superior, seized imperial power. Inevitably, the Pannonian legions supported his claim. Additional support came from other legions of the Rhine and Danubian area, for instance those stationed in Moesia Inferior, the province governed by Severus' brother Septimius Geta. ${ }^{2}$ Tribunus militum Iulius Septimius Castinus and legionary legate Marius Maximus Perpetuus Aurelianus thus sided with Severus at early stages in their senatorial careers. Furthermore, by acclaiming Clodius Albinus, the governor of Britannia, Caesar, Severus secured the support of the three legions stationed there. ${ }^{3}$

2 Septimius Geta is attested as governor of Moesia Inferior in $A E$ 1946, $131=I R T 541$ (Lepcis Magna) and an inscription from Oescus, Moesia Inferior. See Boteva (1996a), 239-240, note 8. On Septimius Geta, see furthermore $P I R^{2} S$ 453. Severus' coinage (BMCRE V, 21, nos. 7-25) shows that at least fifteen of the sixteen legions in Raetia, Noricum, Dacia, the Pannonian, Moesian and German provinces, initially supported him. Cf. Campbell (2005a), 3, note 6. On the year 193 and Severus' initial support, see also Birley (1988), 89-107; Christol (1997), 26-28.

${ }^{3}$ On Iulius Septimius Castinus, see PIR I 566; on Marius Maximus Perpetuus Aure- 
A man named Iulius Laetus led Severus' advance guard during his march on Rome. It is very likely that he is the same man who later played a role in the Parthian wars and Albinus' defeat. ${ }^{4}$ Another man involved was Valerius Valerianus, who as praepositus commanded one of the detachments during this expeditio urbica. Valerianus had previously completed the equestrian tres militiae and served as procurator in Cyprus and cavalry commander (praepositus equitum). ${ }^{5}$

Support within the city of Rome seems to have been arranged as well: if we may believe the Historia Augusta, which reports that Fabius Cilo was appointed consul designatus by Commodus before the latter was murdered, Cilo may well have been consul suffectus in April 193. ${ }^{6}$ At several moments in their careers, Severus and Cilo clearly operated in each other's vicinity. ${ }^{7}$ It is therefore reasonable to assume that they knew each other when Severus was proclaimed emperor. As consul (even if he was still a designatus), Cilo would be a powerful ally in the capital. Iulia Domna's brother-in-law, Iulius Avitus Alexianus, may also have performed useful service for Severus when he marched on Rome: if he was indeed procurator ad annonam in Ostia in 193, and so assisting the praefectus annonae of Rome in the provision, storage and transportation of the corn supply of the capital, as Birley suggests, he was an important man. ${ }^{8}$

lianus, see CIL 6.1450 = ILS 2935 (Roma); PIR ${ }^{2}$ M 308; Birley (1997b), esp. 2694-2703; cf. Chapter 2; on Clodius Albinus, see PIR ${ }^{2} \mathrm{C}$ 1186; Birley (2005), 174-180.

${ }^{4}$ HA, Vita Did. Iul. 8, 1. On Laetus as Severus' commander during the Parthian wars, see Dio 75, 2-3 (pp. 196-197); 75, 9, 1-2. On Laetus, cavalry commander in the battle against Albinus, see Dio 76, 6, 8; Herodianus 3, 7, 3-7; cf. HA, Vita Sev. 11, 2. On Iulius Laetus, see also PIR $^{2}$ I 373.

${ }^{5}$ Valerius Valerianus, according to Birley (1988), 98, possibly of Pannonian origin, was an eques whose career is known to us from an inscription from Caesarea Maritima. Unfortunately, a third of the text was lost when a later inscription was engraved on the same column. Enough has survived, however, to show that Valerianus was a key figure during Septimius Severus' civil wars. By now, several scholars have suggested restorations, so that we have some idea of what his career may have looked like. See Speidel (1985), cf. Fitz (1969).

${ }^{6}$ HA, Vita Comm. 20, 1. On Fabius Cilo, see PIR ${ }^{2}$ F 27.

7 They both commanded a legion in Cappadocia at the beginning of the sole reign of Commodus. Fabius Cilo was legatus legionis XVI Flaviae Firmae which was stationed in Samosata between 180 and 184. Septimius Severus was legatus legionis IV Scythicae which was stationed in Zeugma ca. 182/183. Later, they governed the neighbouring provinces of Gallia Narbonensis and Gallia Lugdunensis at about the same time in the 18 os.

${ }^{8}$ Cf. Birley (2005), 226. On Iulius Avitus Alexianus, see PIR ${ }^{2}$ I 192; Halfmann (1982); Birley (2005), 225-226. 
The Battle against Niger-The Expeditio Asiana (193-194)

Table 4.2. Men involved in the battle against Niger

\begin{tabular}{ll} 
Name & Position \\
\hline Claudius Candidus & Dux exercitus Illyrici 193/194 \\
& Dux adversus rebelles Asiae 194 \\
Cornelius Anullinus & Legatus Aug/Dux exercitus \\
Fabius Cilo & $\begin{array}{l}\text { Comesitus vexillationibus Illyricianis } 193 \\
\text { Legatus Aug pr pr Ponti et Bithyniae 193/194 }\end{array}$ \\
Hedius Rufus Loll. Gentianus & Comes \\
Marius Maximus & Dux exercitus Moesiaci \\
Valerius Valerianus & Praepositus vexillationis adversus hostes \\
& publicos (under Anullinus) \\
\hline
\end{tabular}

After Didius Iulianus was cut out, the senate officially acknowledged Severus as the new emperor. While Albinus secured the northwestern borders, Severus was free to move eastwards and deal with another rival. Pescennius Niger, governor of Syria, had been acclaimed emperor by the troops in Antiocheia at about the same time Severus was proclaimed. ${ }^{9}$ Although Niger had been playing a waiting game for awhile, he now headed for Rome. Severus' first response was to send Fabius Cilo to Perinthus as commander of a number of vexillationes Illyriciani to prevent Niger's troops from advancing any further into Thracia, probably before Severus reached Rome. Apparently, Cilo and his forces were not very successful: many soldiers were slain and Niger advertized a victory on his coins. ${ }^{10}$ After the defeat, that probably convinced Severus that Cilo was more valuable as an adviser than as a commander, the senator joined Severus as comes during the remainder of the expedition. Another comes, the patrician Hedius Rufus Lollianus Gentianus, like Cilo did not have much recent military experience. ${ }^{11}$ Nevertheless, he served as comes thrice at the beginning of Severus' reign, in the expedition against Niger,

\footnotetext{
${ }^{9}$ On the war against Niger, see Birley (1988), 108-120.

${ }^{10}$ HA, Vita Sev. 8, 12-13; BMCRE V, 73-74.

11 As legatus legionis XXII Primigeniae, Lollianus Gentianus was sent to Moguntiacum (modern Mainz) during the reign of Commodus, ca. 184. In those days, Germania Superior was afflicted by unrest caused by the revolt of Maternus, also known as the Bellum Desertorum. On this revolt, see CIL 11.6053, 13.11757; Herodianus 1, 10; HA, Vita Comm. 16, 2; Pesc. Nig. 3, 3-5. See also Alföldy (1989b); Hekster (2002), 65-67, with further references. When the German legion VIII Augusta was besieged in 185, the other legions in the area must have been affected by the unrest as well. On Hedius Rufus Lollianus Gentianus' career, see Christol (1981); and Chapter 2, Excursus.
} 
and later in the first Parthian war and the campaign against Albinus. Birley suggests that Severus and Hedius Lollianus may have met when the former was governor of Lugdunensis and the latter was on his way to Moguntiacum (modern Mainz) to command the legion XXII Primigenia. ${ }^{12}$ Although there is no evidence that they actually met then and there, it is very unlikely that Septimius Severus did not know Hedius Lollianus, or the latter's father, who was one of the more senior senators in those days. Severus must at least have been familiar with the gens, which belonged to the senatorial elite in the late second century, as has been discussed in Chapter 2.

Several other men played a more active role in the battle against Niger, one example being Claudius Candidus. ${ }^{13}$ A special army unit drawn from the Pannonian legions (the exercitus Illyricus) was put under the command of this former eques, who had acquired military experience under Marcus Aurelius and had been supply official in Marcus' second expedition against the Germans. Under Commodus, Candidus had reached the praetorian rank through adlectio. ${ }^{14}$ Fitz's suggestion that Claudius Candidus may have been legatus of one the Pannonian legions at the time of Severus' proclamation would help to explain why the emperor appointed Candidus as dux exercitus Illyrici. ${ }^{15}$ Candidus' appointment could then be seen as a parallel to Marius Maximus, who was promoted dux exercitus Moesiaci from a comparable position. Marius Maximus, the son of a procurator, started his senatorial cursus honorum under Marcus Aurelius and gained considerable military experience as legionary tribune in the Marcomannic war. ${ }^{16}$ After several civil-administrative positions

12 Birley (1988), 76

${ }^{13}$ On Claudius Candidus, see PIR ${ }^{2}$ C 823; Leunissen (1989), 381.

${ }^{14}$ His adlectio was probably one of Commodus' countless appointments to the praetorian rank whereby he obscured the rank's significance, as the Historia Augusta puts it (HA, Vita Pert. 6, 10). Presumably, Marius Maximus was also one of the many men whom Commodus promoted to the praetorian rank by appointment instead of advancement for actual service. Replenishing the senate was probably necessary after the Antonine Plague. Cf. Duncan-Jones (1996); Bagnall (2000); Scheidel (2002); Bruun (2003).

${ }^{15}$ Fitz (1966a), $831 \mathrm{ff}$. Unfortunately, no evidence exists to confirm this hypothesis. It is also possible that Candidus was in Asia Minor when Severus was proclaimed; he had been an assistant of the governor of Asia and subsequently curator of Nicomedia and Ephesus. In that case, someone else was commanding the army and turned over his command to Candidus at his arrival. See Leunissen (1989), 349, note 262, with further references.

${ }^{16}$ Marius Maximus was tribunus legionis twice. Birley (1997b), 2698-2699, points out that the double tribunate was not very common. He suggests (2699, note 52 ), 'that his legate of XXII Primigenia when Maximus was in the legion was either Clemens or 
under Commodus, he became legatus legionis in Moesia Inferior under Severus' brother Geta. In the war against Niger, an army corps drawn from the Moesian legions was thus placed under Marius Maximus' command.

Candidus defeated Niger's ally Asellius Aemilianus at Cyzicus, and shortly thereafter Niger himself at Nicaea. According to Dio, Candidus led masterfully when his soldiers were on the verge of taking flight. ${ }^{17}$ Severus obviously recognized Candidus' leadership qualities: he took regular part in Severus' expeditions in the next few years, as will become clear. After Niger's defeat, Marius Maximus was sent to capture Byzantium with his army, in which he succeeded.

Another general sent against Niger was Cornelius Anullinus. ${ }^{18}$ In 193, he had reached the high senatorial post of governor of Africa Proconsularis. Yet, he was commander-in-chief $(d u x)$ during the battle at Issus. ${ }^{19}$ Anullinus' ancestors are unknown, but given the rather large number of positions he held before his consulate, he almost certainly did not belong to a patrician family. Like Severus, he may have been the son of an eques. He and Severus may have met in Rome at the beginning of their careers, for Severus was to serve under Anullinus as quaestor during the latter's position as governor of Hispania Baetica in 170. Due to Moorish invasions, however, the province was taken out of the senate's control. According to Birley, Severus' appointment to Baetica probably resulted from a request by Anullinus. ${ }^{20}$ Anullinus and Severus might also have had a long-lasting amicitia which went beyond the political sphere. ${ }^{21}$ This would explain why such a senior senator, member of the senatorial elite, agreed to take up this military post.

Valerius Valerianus was also deployed again: after his success during the march on Rome, he led a detachment, possibly the same one as

Cerealis, and that he moved to Raetia when his immediate commander was promoted to be governor there.' On Marius Maximus' father, L. Marius Perpetuus, see PIR ${ }^{2}$ M 313; Plaum (1960-1961), vol. 1, 411-414, no. 168; On Marius Maxinus' ancestors, see also Birley (1997b), 2695-2697.

${ }_{17}$ Dio 75, 6, 5-6.

18 On Cornelius Anullinus, see $P I R^{2} \mathrm{C}$ 1322; Thomasson (1996), 77-78, no. 100.

19 According to Dio 75, 7, 1-8, Anullinus was 'dux Severi imperatoris in Oriente'

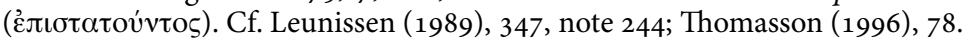

${ }^{20}$ Birley (1988), 40; 49.

${ }^{21}$ Birley (1988), 112; 122. Birley even calls Anullinus 'Severus' senior marshall'. The idea of amicitia between Severus and Anullinus is strengthened by the fact that the emperor granted Anullinus a house in Rome, according to Epitome de Caesaribus 20, 6. 
before, to Asia Minor to join the battle against Niger. Under Anullinus he commanded the cavalry at Issus. ${ }^{22}$

When the provinces that Niger had won were recaptured, order had to be restored. Claudius Candidus was sent back into Asia with at least part of his army to pursue the remaining supporters of Niger, who were declared public enemies as dux adversus rebelles. Fabius Cilo was appointed governor of Bithynia et Pontus. He may have had to deal with some supporters of Niger as well, although no specific mention of them was made in the sources. To ensure that no future governor of Syria would take up the idea of proclaiming himself emperor, the province was split in two, Syria Coele and Syria Phoenice. ${ }^{23}$

\section{The First Parthian War-The Expeditio Mesopotamena (195)}

Table 4.3. Men involved in the first Parthian war

\begin{tabular}{ll} 
Name & Position \\
\hline Claudius Candidus & Dux exercitus Illyrici \\
Cornelius Anullinus & Legatus Aug/Dux exercitus \\
Hedius Rufus Loll. Gentianus & Comes \\
Iulius Laetus & General $($ dux? $)$ \\
Probus & Commander of a field army (dux exercitus?) \\
Sextius Magius Lateranus & Dux exercitus \\
Valerius Valerianus & Praepositus summae expeditionis \\
\hline
\end{tabular}

Immediately after Niger's defeat, Severus needed to strengthen his authority in the East. He started a punitive campaign against the Parthians, who had supported Niger. Since Severus could not afford to offend the Parthians directly, the so-called expeditio Mesopotamena aimed at the Osrhoeni of Mesopotamia and 'Arabs' and 'Adiabenians', supposedly Parthian vassals. ${ }^{24}$

In his account of the expedition against the Osrhoeni and the Adiabeni, Dio mentions three generals: Lateranus, Candidus, and Laetus. ${ }^{25}$ Of these, Claudius Candidus commanded the Illyrian army again as $d u x$.

22 Dio 75, 7, 1. According to Speidel (1985), 325, this detachment was Danubian.

${ }^{23}$ Birley (1988), 114-115, with further references.

${ }^{24}$ Dio 75, 1, 1 (pp. 194-195) The name expeditio felicissima Mesopotamena for Severus' first Parthian war appears in Valerius Valerianus' career inscription $(A E$ 1991, $1579=$ $A E$ 2001, 01968, Palaestina) and ILS 9098 (Numidia). Cf. ILS 1144 (Roma). See Speidel (1985), 324. On the expedition, see also Birley (1988), 115, with further references.

${ }^{25}$ Dio 75, 2, 3 (pp. 196-197). 
As noted above, Laetus was probably the same man who had led the advance guard on its march into Rome in 193. The third general, Sextius Magius Lateranus, belongs to the group of patrician consulars. His father had been consul ordinarius as colleague of Lucius Verus in 154, and his grandfather Sextius Cornelius Africanus had been consul ordinarius in 112 with the emperor Traianus. ${ }^{26}$ The Septimii were acquainted with the Sextii: Septimius Severus' relative Gaius Septimius Severus (consul suffectus in 160) had participated in a consilium of Marcus and Commodus in 177 along with Sextius Magius Lateranus' father. ${ }^{27}$

In the battle against the 'Arabs', Severus again divided the imperial field army into three units. According to Dio, the divisions were commanded by Laetus, Cornelius Anullinus and one Probus, who is otherwise unknown. ${ }^{28}$ Furthermore, Valerius Valerianus was involved in this battle. Perhaps he was linked to Anullinus again, as he had been in the battle at Issus. Valerianus' career inscription calls him praepositus summae [felicissimae expeditionis] Mesopotamenae. It seems that, after Septimius Severus had initially commanded the expedition, Valerianus was entrusted with finishing off the Mesopotamian campaign against the Arabs. In the meantime, the emperor himself went to Gallia with his armies to fight Clodius Albinus. If this is correct, Valerianus held the strategically most important position in Mesopotamia at that point. As Speidel argues, 'his command over the last phase of the Mesopotamian campaigns proves that Valerianus was one of Severus' most trusted field commanders in AD 195. ${ }^{29}$ In 197, however, as an attack of the Parthians asked for more drastic interference, the higher-ranked general Laetus was called back to Mesopotamia.

${ }^{26}$ Sextius Magius Lateranus' full name was T. Sextius Lateranus M. Vibius Ovel[lius? ...] Secundus L. Vol[usius Torquatus?] Vestinus. On him, see PIR ${ }^{2}$ S 666. T. Sextius Magius Lateranus (consul ordinarius 94), and T. Sextius Africanus, (consul suffectus 59), may have been his ancestors. His ancestry has even be traced back to the Republican Sextii from Ostia. See stemma 16 in PIR ${ }^{2}$, pars VII, fasc. II, 257.

27 AE 1971, 534 (Banasa, Mauretania Tingitana). Sextius Magius Lateranus' father, Sextius Lateranus, was mentioned third on the list of consiliarii, C. Septimius Severus is the fourth one who is mentioned. For further discussion of this inscription, see SherwinWhite (1973).

${ }^{28}$ Dio 75, 3, 2 (pp. 198-199).

${ }^{29}$ Speidel (1985), 326. 


\section{The Struggle against Albinus-The Expeditio Gallica (195-197)}

Meanwhile, hostilities between Severus and his former ally Clodius Albinus had increased. By giving his elder son Caracalla the title Caesar, Severus deprived Albinus of any hope of succeeding to the Principate. In reaction, Albinus may have contacted senators on the possibility of a revolt. ${ }^{30}$ Although the course of events has been unclear, the result was a decisive break between Severus and Albinus. By the end of 195, after Severus' declared him a public enemy, Albinus responded by proclaiming himself emperor and invading Gallia. ${ }^{31}$

Table 4.4. Men involved in the battle against Albinus

\begin{tabular}{|c|c|}
\hline Name & Position \\
\hline Claudius Candidus & $\begin{array}{l}\text { Dux adversus rebelles Noricae } 196 \\
\text { Dux exercitus Illyrici 196/197 }\end{array}$ \\
\hline Claudius Claudianus & $\begin{array}{l}\text { Legatus legionis XIII Geminae et V } \\
\text { Macedonicae (Dacia) 194?/195-196? } \\
\text { Praepositus vexillationum Daciscarum } \\
196 ?-197\end{array}$ \\
\hline Fabius Cilo & $\begin{array}{l}\text { Legatus Aug pr pr Moesiae Superioris } 195 \\
\text { Dux vexillationum per Italiam exercitus } 196 \\
\text { Legatus Augg pr pr Pann. Sup. 197-201 / 202? }\end{array}$ \\
\hline Hedius Rufus Loll. Gentianus & Comes \\
\hline Iulius Avitus Alexianus & $\begin{array}{l}\text { Legatus legionus III[I] Flaviae (Moesia Sup.) } \\
\text { Legatus Augg pr pr Raetiae }\end{array}$ \\
\hline Iulius Laetus & Cavalry commander (dux/strategos) \\
\hline Iunius Faust. Pl. Postumianus & Legatus legionis I Adiutricis in Pannonia Sup. \\
\hline & Dux exercitus Moesiaci \\
\hline Septimius Geta & Legatus Aug pr pr Daciae \\
\hline Virius Lupus & Legatus Aug pr pr Germaniae Inferioris (dux?) \\
\hline
\end{tabular}

Virius Lupus, governor of Germania Inferior, was mobilized by Septimius Severus to solve the problem. He acted as general in a battle against Albinus, but was defeated and many of his soldiers were slain. ${ }^{32}$ After

\footnotetext{
${ }^{30}$ Cf. HA, Vita Sev. 10, 2.

${ }^{31}$ On the war against Albinus, see Birley (1988), 121-128.

32 Dio 76, 6, 2. Cf. HA, Vita Sev. 10, 7. Some scholars assume that he was a general with a special commission, but Leunissen (1989), $242 \mathrm{f}$., argues that Dio would not have used the word strategos in that case. Leunissen finds it more likely that the governor Virius Lupus commanded the provincial legions. On Virius Lupus, see Chapter 2, Excursus.
} 
initial success of Albinus' armies, the tide began to turn early in 197. Eventually Albinus and his army were defeated near Lugdunum. ${ }^{33}$

Several names of officers involved in the conflict with Albinus have come down to us. Again, Claudius Candidus was deployed with his exercitus Illyricus. When he was on his way to the West with his army in 196, he again had to pursue some rebels, this time probably followers of Albinus, in Noricum. In 197, Candidus, who had by then reached consular rank, participated in the battle at Lugdunum. Marius Maximus was also involved: he led his Moesian army from captured Byzantium to Lugdunum and joined the fight.

A new name pops up among the officers: Claudius Claudianus. This man may have been identical with the Claudius Claudianus who, as equestrian praefectus cohortis I Bracaraugustanorum, dedicated an altar to Diana Nemorensis in Dalmatia.. ${ }^{34}$ In 195 , Claudius Claudianus took up a legionary command over two legions stationed in Dacia. Septimius Geta, Severus' brother, was governing Dacia at that time. In 196, a special force was formed from within the Dacian army to participate in the battle against Albinus. Claudianus was to command these vexillationes, perhaps accompanied by Geta. ${ }^{35}$

The leading role, however, in the final battle against Albinus at Lugdunum went to Laetus as cavalry commander. According to Dio's account, Severus and the praetorians came to the aid of the Severan troops when they saw them in danger. As the situation worsened and Albinus' troops forced the Severans into retreat, the emperor fell off his horse. At that point, with the emperor's life imperiled, the Severan cavalry under command of Laetus appeared and saved the day. So Laetus won the victory against Albinus for Severus. Dio suggests that Laetus waited before he intervened, allegedly hoping that both Severus and Albinus would get killed so that he himself could be proclaimed emperor. Moreover, Dio claims that Laetus only reacted when he saw that Severus' side was prevailing. The same suggestion can be found in the work of Herodianus. ${ }^{36}$ The story on Laetus' betrayal may have been made up after his death.

Some others played a minor role in Albinus' defeat. First, Hedius Rufus Lollianus Gentianus again advised Severus as comes. Fabius Cilo had

${ }^{33}$ Battle at Tinurtium: HA, Vita Sev. 11, 1. Battle at Lugdunum: Dio, 76, 6.

${ }^{34}$ ILS 3245 (Narona, Dalmatia). On Claudius Claudianus, see $P I R^{2}$ C 834; Leunissen (1989), 382 .

35 On Geta as governor of Dacia, see Leunissen (1989), 237, with further references.

${ }^{36}$ Dio 76, 6, 8; Herodianus 3, 7, 3-7. 
been transferred to Moesia Superior in 195, no doubt because Severus wanted to put the northern provinces into trusted hands in anticipation of his conflict with Albinus. ${ }^{37}$ Second, in the second half of 196, Cilo commanded detachments of the Italic army which escorted Severus back to Rome on his way from Mesopotamia. Since Fabius Cilo became governor of Pannonia Superior in 197, it is reasonable to assume that he escorted the emperor only as far as this province. ${ }^{38}$ Third, Avitus Alexianus probably served under Fabius Cilo as legatus legionis IV Flaviae, and later was sent to govern Raetia. Whether Avitus Alexianus played a more active role in the defeat of Albinus is unclear. ${ }^{39}$

New men might have ascended, such as Iunius Faustinus Placidus Postumianus. ${ }^{40}$ Most scholars assign this senator's career to the joint reign of Severus and Caracalla, after he had probably started his senatorial cursus under Commodus as the emperor's candidatus as tribunus plebis and praetor, which indicates patrician status. ${ }^{41}$ It was presumably Severus who appointed him iuridicus in northern Italy. Postumianus' next position was his first military one: he became legatus of I Adiutrix, one of the legions which had supported Severus. By 196/197, the legion must have been back at its main base in Brigetio in Pannonia Superior. It is not unlikely that Severus marched against Albinus in Lugdunum via Pannonia, gathering additional forces in the Danubian area. Perhaps legio

37 Cilo may have been present when Caracalla was elevated to the rank of Caesar, probably near Viminacium, capital of Moesia Superior, in (April?) 196. The same applies to Iulius Avitus Alexianus, legionary legate in Moesia Superior in those days. Cf. Birley (1988), 122.

38 Birley (1988), 124. According to Birley, Caracalla was left behind with Fabius Cilo in Pannonia Superior.

${ }^{39}$ Leunissen (1989), 280. In Alexianus' cursus inscription $A E$ 1921, $64=A E$ 1963, 42 (Dalmatia), he is called legatus pro praetore provinciae [Raetiae]. In an earlier dedication to the god Elagabalus from when he was governor of Raetia $(A E 1962,229$, Raetia), he is called praeses. Whether the term indicates military activity is uncertain.

40 The main part of Iunius Faustinus Placidus Postumianus' career can be deduced from his cursus inscription CIL 8.597 (Africa Proconsularis). A funerary inscription set up by his son and daughter (CIL 8.11763, Africa Proconsularis), lists the final part of his career. See Birley (2005), 192-193. It is very likely that the two inscriptions are related to one and the same person. However, it is also possible that the latter inscription refers to a descendant of the Postumianus in the former inscription. On Postumianus' see also PIR I 751 , cf. 752.

${ }^{41}$ Except for Fitz (1966b), $25 \mathrm{ff}$., who suggests a date under Marcus Aurelius. Against his dating, see Alföldy (1969), 50 ff.; cf. Birley (2005), 193-194, who warns that the reconstruction of Postumianus' career under Septimius Severus and Caracalla rests on fragile foundations, as the two Augusti in the formula adlecto inter comites Augg nn may even be Valerianus and Gallienus and the governorships could have been held under those emperors and their predecessors in the $240 \mathrm{os}$ and $250 \mathrm{os}$. 
I Adiutrix even participated in the battle against Albinus. This would explain the further course of Postumianus' career.

\section{The Second Parthian War (197-198)}

Soon after Albinus' death, Severus focused on the East again. He decided to deal with the Parthians once more after they had taken Mesopotamia, levying three new legions for the occasion. The northern half of Mesopotamia was restored to Rome. Yet, two attempts to seize the strategically important city of Hatra failed. ${ }^{42}$

The only officer involved in this second Parthian war known to us was Laetus. In the autumn of 197 , he was sent to relieve the city of Nisibis which the Parthians were about to seize. ${ }^{43}$ Laetus succeeded and acquired still greater renown. His popularity with the soldiers became manifest at Hatra in 198, when the soldiers declared that they would not go on a campaign unless Laetus led them. As this threatened his own position, Severus decided that enough was enough, and Laetus was put to death, though Severus obviously denied that Laetus was killed on his orders. ${ }^{44}$ This renders suspicious the story of Laetus' betrayal in Lugdunum, as a possible example of ex morte vilification. If there really had been any reason for Severus to believe that Laetus betrayed him at Lugdunum, Severus would have been taking a great risk by sending Laetus to relieve Nisibis by himself. Although Laetus probably remained close to the emperor during the second Parthian war, there is no mention of him holding any field commands after he rescued Nisibis, which may suggest that the emperor only then started to distrust Laetus.

Peace in the Empire (198-208)

When the civil and Parthian wars were over, there was peace in the Empire for about ten years. What happened with Severus' military officers during this period?

Sextius Magius Lateranus was only in action during the first Parthian war. Afterward, he was rewarded with an ordinary consulate in 197. Eck has suggested that Lateranus may have been proconsul Asiae, but offers no

${ }^{42}$ Dio 76, 9-10. On the second Parthian war, see Birley (1988), 129-145.

${ }^{43}$ On Laetus' actions in the first Parthian war, see Dio 75, 2-3 (pp. 196-197); Birley (1988), 116-117.; on the second Parthian war, see Dio 76, 9, 1-2; Birley (1988), 127-129.

${ }^{44}$ Dio $76,10,1-3$. 
date. ${ }^{45}$ Cornelius Anullinus' role as a military officer was also over after 195. He was appointed city prefect of Rome in 196 and held a second consulate in 199. Hedius Rufus Lollianus Gentianus became censitor in 197/198 in Gallia Lugdunensis and perhaps also in Hispania Citerior in the next year. After Albinus' defeat, many nobles in those areas who had sided with him were put to death, 'a census would be badly needed there at that point.' ${ }^{46}$ In 201, Hedius Lollianus concluded his senatorial career as proconsul Asiae. Fabius Cilo stayed in Pannonia Superior for some more years, governing this strategically crucial province when Severus was fighting Albinus and the Parthians, before he succeeded Anullinus as city prefect in Rome. He held this position until the end of Severus' reign and combined it with a second consulate in 204. Cilo, Lateranus and Anullinus were apparently imperial amici who were enriched and endowed with houses in the capital by the emperor, according to Aurelius Victor. ${ }^{47}$

As for Severus' relatives, Geta held a second consulship in 203 with Plautianus as his colleague, and probably died not long afterwards. ${ }^{48}$ Avitus Alexianus remained in his position as governor of Raetia until circa 199/200 and held a suffect consulship, perhaps in absentia, circa 200. Thereafter, he seems to have been out of office for almost eight years. ${ }^{49}$

Immediately after Albinus' defeat, Marius Maximus was made governor of Gallia Belgica. The decision to put a strong military leader in this province is understandable considering the trouble in the north-west in the years before, especially in Britannia, which had been deprived of Roman legions for some time. During or shortly after his position in Belgica, Marius Maximus held a suffect consulship. As vir consularis, he was first sent to govern Germania Inferior and then to Syria Coele. After his post in Syria, his career seems to have experienced a currently inexplicable hiatus, though Birley notes that something similar seemed to have

${ }^{45}$ Based on $S E G$ 36, 1094. For Eck's suggestion, see PIR ${ }^{2} S$ 669. The fact that Lateranus' father was proconsul of Africa $(168 / 169)$ corroborates this assumption, as the family thus belonged to the senatorial elite.

46 Birley (1988), 126.

47 Fabius Cilo was attested as amicus Augustorum, see Epitome de Caesaribus 20, 6. According to Birley (1988), 156, the 'domus Cilonis' was a palatial mansion and became a city landmark. Cf. Alföldy (1968), 134; 141-142; 159.

48 On Geta's death, see Dio 77, 2, 4.

49 Birley (2005), 226, ascribes this long period in which Avitus Alexianus was out of office to the influence of Plautianus, who was hostile to Iulia Domna and her family. He adds that Varius Marcellus, Alexianus' son-in-law, experienced similar treatment. 
occurred in the career of his brother Marius Perpetuus. ${ }^{50}$ Claudius Claudianus' case resembled that of Marius Maximus: after Albinus' defeat, he governed Pannonia Inferior, during which tenure he held a suffect consulate, and then governed Pannonia Superior until circa 206.

Claudius Candidus, who had probably held a consulate before or during the expeditio Gallica, was sent to govern Hispania Tarraconensis in 197-198. He was entrusted with the special task of hunting for rebels, i.e. remaining supporters of Albinus. Nothing is heard of him afterwards. Since his name was erased from his statue base at Tarraco, we may assume that he fell into disfavor with the emperor and was perhaps executed. ${ }^{51}$ This may have happened shortly after the incident with Laetus.

Valerius Valerianus never served in a military office under Severus again, and his career may not have continued under Severus at all. Perhaps his appointment as procurator of an unknown province fell under Severus, but his posts as procurator of Syria Palaestina and praefectus Mesopotamiae et Osrhoenae probably fell under Caracalla. ${ }^{52}$ Eventually, therefore, Valerianus reached one of the top positions of the equestrian career, but only after Severus died. ${ }^{53}$

Iunius Faustinus Placidus Postumianus was made governor of Hispania Lusitania circa 197. The province had supported Albinus and probably experienced prosecutions of Albinus' supporters during Postumianus' term. ${ }^{54}$ The governorship thus was more important in those years than it usually was. Next, Postumianus succeeded Marius Maximus as governor of Belgica and probably became consul suffectus after this

${ }^{50}$ According to Birley (1997b), 2699, the high favor that they both enjoyed under Caracalla may be a sign of a lack of favor under Severus caused by Plautianus' dominant position. Previously, Birley (1988), 176, had excluded the possibility that Marius Maximus fell out of favor with Severus, as the former was in high favor in the next reigns.

${ }^{51}$ Candidus' name was erased from CIL 2.4114 = ILS 1140 (Hispania Citerior). He might have been one of the friends of Severus who were tried on the ground that they were plotting to kill the emperor, as HA, Vita Sev. 15, 4-6 mentions. The author of the Historia Augusta claims that Plautianus was behind this.

52 Duncan-Jones (1969) argued that the position of praefectus Mesopotamiae et Osrhoenae only existed from 212 / 213, when Caracalla deposed Abgar IX as king of Edessa, until the revival of the kingdom Edessa under Gordianus III. Valerianus' position as procurator Syriae Palaestinae may also have been held under Elagabalus.

${ }^{53}$ Although Duncan-Jones (1969) does not link the L. Valerius Valerianus who is mentioned on the epitaph from Pozzuoli to the equestrian commander during Severus' civil wars, it is very likely that they were identical. The new provinces of Mesopotamia and Osrhoene were equipped with two newly raised legions (I and III Parthica). See Dio 55, 24, 4, and Duncan-Jones (1969), 231.

${ }^{54}$ Leunissen (1989), 51, note 116. 
governorship, circa 204/5. He was then sent to govern Moesia Inferior for some time between 205 and 208. Birley claims that his tenure may have been very brief, since Postumianus' name does not appear on the local coinage. ${ }^{55}$

Iulius Septimius Castinus precipitated the only actual military activity in this period. He may have been a kinsman of Severus, bearing the same gentilicium. ${ }^{56}$ Castinus' career started at the end of Commodus' reign, and he was likely tribunus militum of I Adiutrix under Septimius Severus in Pannonia. Perhaps he served under Geta next as tribunus of $V$ Macedonica. Both legions had supported Severus in 193. After several civil positions, Castinus became legionary legate of I Minervia, which was by then stationed at Lugdunum. Between 205 and 208, he was made dux of several vexillationes formed from legio I Minervia and three other legions stationed in the Rhine area. These vexillationes were mobilized 'against the disloyal and rebellious ones', but it is not clear who these rebels were. ${ }^{57}$

Finally, Virius Lupus. Immediately after the defeat of Albinus and the British army at Lugdunum, Lupus was sent to govern Britannia, a sequence which was not unusual. ${ }^{58}$ The position of the Romans in the north of the province of Britannia was weak when Lupus arrived. In the absence of most of the Roman garrison in 196-197, northern Britannia had been plundered by the Maeatae, who were probably joined by some other tribes. This had led to serious destruction and many Roman captives. Lupus had to buy off the Maeatae, who were at the point of bringing in the Caledonii. ${ }^{59}$ Britannia had been a troublesome province ever since the death of a governor in a barbarian invasion circa $182 / 183$ and the campaigns of Ulpius Marcellus, followed by discontent and mutiny in the British legions. Lupus is not heard of again. He was probably replaced

55 Birley (2005), 194, note 40.

56 Jacques (1982), 85, note 2, warns that 'Septimius' is a nomen gentile that occurs often. On his origin: Kajanto (1965), 251-252, mentions that 'Castinus' is very rare, but 'Castus' is popular in Africa, and 'Iulius Castus' occurs there sixteen times. See also Birley (1988), 215 no. 19, and Leunissen (1989), 363.

57 According to Alföldy (1967), 51, Castinus was dux circa 206-208, before his post as legionary commander in 208. As $d u x$ he had to defeat the remaining supporters of Clodius Albinus. Eck (1972/1973), 248-249, and id. (1985), 249, no. 77, agrees with Alföldy. Corbier (1973), 654, and Piso (1982), 381, note 51, think Castinus was legatus legionis before he was appointed $d u x$. Cf. PIR ${ }^{2}$ I 566; Leunissen (1989), 337, note 177. For my purposes, the exact order of the positions is irrelevant.

58 Leunissen (1989), 242.

59 Dio 75, 5, 4 (pp. 216-217). 
after about three years, in 200. Perhaps Severus consulted him as former governor and specialist of Britannia before he went on his expedition.

\section{The Expeditio Britannica (208-211)}

Table 4.5. Men involved in the expeditio Britannica

\begin{tabular}{ll} 
Name & Position \\
\hline Alfenus Senecio & Legatus Augg pr pr Britanniae 205/ 207? \\
Iulius Avitus Alexianus & Comes Augg \\
Iunius Faust. Pl. Postumianus & Comes Augg \\
Oclatinius Adventus & Procurator Augg in Britannia 205-207? \\
\hline
\end{tabular}

In 208, Severus decided to go to Britannia to settle the conflict there. Preparations for the military expedition may have been started by Alfenus Senecio, when he was governor of the province between 205 and $207 .{ }^{60}$ Severus may have met him when Senecio was governor of Syria Coele circa 200, at the time the emperor and his family were travelling in the East. ${ }^{61}$ Senecio may still have been in Britannia in the spring of 208, when Septimius Severus arrived with both his sons. ${ }^{62}$ Unfortunately, we lack any more details of the beginning Senecio's career. However, it is not unlikely that Senecio was a trusted servant of the emperor who had perhaps served the emperor well during the Parthian wars. In this respect, he may be compared to his predecessors in Britannia, Virius Lupus and Valerius Pudens, who had been governor of Pannonia Inferior in 193. They had both supported Severus in the civil wars.

It is also possible that Oclatinius Adventus, who served as (financial) procurator under Senecio and whose name appears on some inscriptions beside Senecio's, was sent to the island to make preparations for the impe-

60 See Birley (2005), 191. Valerius Pudens is still attested in Britannia in 205. Senecio was probably his successor, so he probably was in Britannia from 205, or soon after. On Alfenus Senecio, see PIR A 520; Birley (2005), 188-192.

${ }^{61}$ An equestrian procurator named Alfenus Senecio, see was honored with an inscription (and presumably a statue) by the council at Cuicul (CIL 8.9046). The inscription mentions that he was procurator Augusti Belgicae. Other inscriptions (ILS 8391, Misenum; CIL 14.4509, Ostia) demonstrate that he was also procurator Mauretaniae Caesariensis, subpraefectus of the Misenum fleet and subpraefectus vigilum. It is generally assumed that this man was the father of the governor of Britannia and that he held these appointments in the reigns of Marcus Aurelius and Commodus. See Birley (2005), 190191; cf. $P I R^{2}$ A 520.

${ }^{62}$ Birley (2005), 161. 
rial expedition, circa 205-207. ${ }^{63}$ In that case, Adventus' arrival may have sidelined Senecio. ${ }^{64}$ Adventus seems to have overseen the pay and provisioning of the army. However, Rankov suggests that, given Adventus' previous career in military intelligence, Severus may have sent him with the special task of recruiting and training scouts, and of gaining information about local conditions and the strength of the tribes north of Hadrian's Wall. ${ }^{65}$

Iunius Faustinus Placidus Postumianus and Iulius Avitus Alexianus joined Severus as comites during the expedition. ${ }^{66}$ Postumianus may have fulfilled his position as praeses Britanniae during the imperial expedition, as successor of Alfenus Senecio, but his tenure may also have taken place under Caracalla. ${ }^{67}$

\section{The Aftermath}

The fates of Severus' military officers after the emperor's death varied. As has been mentioned above, several of them had already disappeared under Severus. Of these, some vanished mysteriously in what seems to have been the midst of their careers, such as Claudius Candidus and Claudius Claudianus. Others had reached the top of the senatorial cursus honorum and may just have retired, such as Anullinus, Lateranus and Hedius Lollianus. Fabius Cilo was still city prefect under Caracalla, yet shortly after Geta's murder he was attacked and humiliated by some soldiers. Dio reports that it was Caracalla who had commanded the soldiers to kill the city prefect, but Caracalla stopped them when the

${ }^{63}$ ILS $2618=$ RIB $1234+$ add.; RIB 1462 (Britannia). Birley (2005), 192, suggests 'that Adventus, whose background was rather unusual for a financial procurator [...] had been specially ordered by Severus to inspect the state of the northern frontier because the emperor was contemplating a personal intervention in Britain.' On Adventus, see PIR ${ }^{2}$ O 9; Rankov (1987); Birley (2005), 312-313, with further references.

64 Herodianus 3, 14, 1, claims that the governor had sent a letter to the emperor in which he asked him for help. This may, however, have been a rhetorical topos, since Dio $(77,10,6$ 'wars being won in Britain') suggests that the governor had been dealing with the situation quite well. On this, see Birley (1988), 172, and Birley (2005), 192. It is also relevant that Adventus' career seems to have stopped for a while. We have no information on positions which he occupied under Septimius Severus after his procuratorship, though his career continued under Caracalla.

65 Rankov (1987), 247-249.

66 On the comites in Britannia, see Alföldy (1969), 49 ff., and Birley (2005), 225-226.

67 Neither Inferior nor Superior appears in the inscription CIL 8.11763 (Africa Proconsularis). This may indicate that he was governor of an undivided Britain, though this cannot be stated with certainty. Cf. Birley (2005), 194. 
populace as well as the city troops began to protest. ${ }^{68}$ Soon afterwards, Cilo was replaced as city prefect, and nothing is heard of him anymore. Perhaps he indeed fell out of favor with Caracalla. Whatever the reason, it is not unlikely that he retired, after having reached the pinnacle of the senatorial career.

Marius Maximus continued his career under Caracalla. He became proconsul of Africa and even served as proconsul of Asia for a double term, at a time when the emperor was present in the province. ${ }^{69} \mathrm{An}$ extended tenure such as his and the fact that he governed both proconsular provinces, were unprecedented. Caracalla obviously held Marius Maximus in high regard, but even after Caracalla's death he was praefectus urbi under Macrinus and consul iterum as Severus Alexander's colleague in $223 .^{70}$ This first generation senator, who began his career as military officer under Septimius Severus, eventually joined the senatorial nucleus described in Chapter 2. After Severus' death, however, he never again served in offices involving much military power.

The same applies to Valerius Valerianus and Iunius Faustinus Placidus Postumianus. Valerius Valerianus' career probably continued under Caracalla. Although his experience in the military sphere may have proven useful during his procuratorships, Valerianus no longer received special commissions in military crises. As prefect of Mesopotamia he reached an equestrian top position, but he never attained senatorial rank. Postumianus, after his post as praeses Britanniae, was made praeses Hispaniae, probably in Hispania Citerior. ${ }^{71}$

Only three of the men involved in military events under Severus continued in offices which entailed some military responsibility. Iulius Avitus Alexianus became praefectus alimentorum twice and was imperial comes again, probably in 213 during Caracalla's German wars. The reason for his

${ }^{68}$ Dio 78, 4-5, refers to Cilo as Caracalla's benefactor and tutor.

${ }^{69}$ IGRR 4.1287. Caracalla visited Thyatira during Marius Maximus' proconsulate.

70 According to Leunissen (1989), 310, Marius Maximus was probably replaced as city prefect before 219, since not Marius Maximus, but Q. Tineius Sacerdos was consul (II) ordinarius with the emperor as his colleague in 219.

${ }^{71}$ Problematic in Postumianus' case is that the dating of his career cannot be determined with certainty. Birley admits that a dating in the 240 os and 250 s is just as well possible. In that case, the significance of the positions as legatus of legion I Adiutrix and as governor in Lusitania and Belgica would be almost entirely lost. Another problem is that we cannot be sure whether the praeses Hispaniae et Britanniae is identical with the man of the cursus inscription of CIL 8.597 (Africa Proconsularis). Postumianus is not mentioned in the historiographical sources. 
repeated appointment as praefectus alimentorum is unclear. ${ }^{72}$ Perhaps it was just convenient to appoint an experienced man at this position. After all, Alexianus had probably also been assisting a praefectus alimentorum at the beginning of his career as procurator in Ostia. Then, Alexianus governed Dalmatia. His term of office was probably not longer than a year and a half. At the end of Caracalla's reign, Alexianus presumably became proconsul of Asia and in 216/217 he seems to have accompanied Caracalla as comes in Mesopotamia. ${ }^{73}$ According to Dio, Alexianus was sent

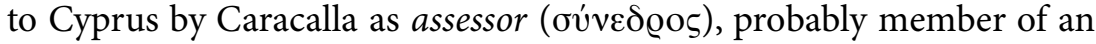
equestrian governor's consilium. In view of Cyprus' location, it logically was relevant in the war's provisioning and Alexianus, with his experience in logistics and food supply, may have advised the governor on this matter. ${ }^{74}$ On Cyprus, Alexianus died from old age and sickness, probably already in 217 , but certainly before Elagabalus ascended the throne in June $218 .{ }^{75}$ Although he was never mobilized by Caracalla at actual military commands, he was involved in positions concerning military logistics.

Iulius Septimius Castinus, after he governed Pannonia Inferior until 212, was sent to govern Dacia circa $215 .{ }^{76}$ Under Macrinus, Castinus was exiled and he spent the rest of his life in Bithynia. Eventually, he was mur-

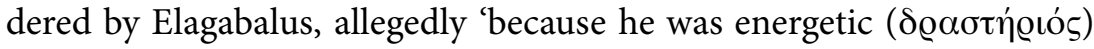
and was known to many soldiers in consequence of the commands he had held and of his intimate association with Antoninus', as Dio puts it. ${ }^{77}$ The literary sources refer to an association between Castinus and Caracalla-Dio even mentions friendship ${ }^{78}$ - but they never state kinship. Either way, Castinus must have owed the responsible military tasks

72 It had happened before, under Marcus Aurelius or Commodus, that the same man, Pollienus Auspex, was appointed at this position even thrice. See Halfmann (1982), 222, note 19.

73 On the date of his proconsulship, see Leunissen (1989), 225. According to Pflaum (1979), 313, Avitus Alexianus joined Caracalla in Mesopotamia during his war against the Parthians. However, Barnes (1986), 204, doubts this. Cf. Leunissen (1989), 225, note 67.

74 Alexianus was sent to Cyprus with a special task. Usually, Cyprus was governed by a praetorian proconsul. However, the island was governed by unusual officers in those years. The governor at the time of Alexianus' appoint was probably the equestrian procurator T. Caesernius Statianus [Quinc] tianus. Halfmann (1982), 223, note 22.

75 Dio 79, 30, 4 .

76 Dio $79,13,3-4$.

77 Dio $80,4,3$.

78 Dio 79, 13, 2. PIR I 566, calls Castinus comes of Caracalla, but this probably is a mistake. There is no indication that Castinus joined the emperor on a journey. On the contrary, Castinus was governing Dacia when Caracalla was in Bithynia (Nicomedia), 
he received after a series of civil offices to some sort of special connection with the imperial household.

Finally, Oclatinius Adventus, who became praefectus praetorio under Caracalla. Like his colleague Macrinus, Adventus joined Caracalla during the Parthian expedition in Mesopotamia. As a man of military experience, Adventus may have actually commanded the praetorians during this campaign. ${ }^{79}$ By the end of May 216, Caracalla honored him with the ornamenta consularia. ${ }^{80}$ Macrinus elevated Adventus to senatorial rank through an adlectio inter consulares in April 217, appointed him praefectus urbi in the same year and made him fellow-consul in 218. ${ }^{81}$ Adventus was soon replaced by Marius Maximus as city prefect, but he continued as consul even after Macrinus was overthrown by Elagabalus. ${ }^{82}$ After this, nothing is heard of Adventus. Given his old age, it is not unlikely that he died soon afterwards.

\section{Concluding Observations}

Examining the men commissioned as high-ranking military officers by Severus leads to the following observations considering power and status: in the very late second and early third centuries, senators could obviously still exercise a high level of power in the military sphere. Severus himself was representative of senatorial viri consulares, who governed

Syria (Antiocheia) and Egypt (Alexandria). If Castinus was indeed comes of Caracalla, this may be an indication that it had become an honorary title.

79 Pflaum (1960-1961), vol. 2, 666, no. 247.

${ }^{80}$ HA, Vita Macr. 4, 7, records that Macrinus' fellow-prefect was sent away ('collega ablegato') when Caracalla was murdered. The name Adventus is not specifically mentioned, and it is not clear whether the phrase has a negative connotation. Magie (19601961, Loeb), vol. 2, 57, translates 'after his colleague was banished', but Adventus might have been sent away on a mission by the emperor. There is no indication that Adventus had fallen out of favor with Caracalla, who had granted him consular honors the year before. On the contrary, the words might have been added to absolve Adventus from any involvement in Caracalla's murder.

${ }^{81}$ Dio 79, 14, who mentions that Macrinus was critized by many because of Adventus' elevation, since 'he could neither see by reason of old age nor read for lack of education nor accomplish anything for want of experience', but especially since 'he had obtained the rule over the city prior to performing the duties of the consulship.' Dio even claims that Macrinus' purpose in elevating Adventus was 'throwing his own record into the background, since he himself had seized the imperial office while still a knight'. It is not difficult to explain Dio's contempt, since he as a senator would certainly be offended to see the new equestrian emperor ignore the principles of senatorial promotion.

${ }^{82}$ Dio 80, 8, 2. 
imperial provinces and in that capacity held supreme commands over provincial legions. Especially governors of provinces with two or three legions could become an immediate threat to imperial authority: those senators had the means (money and troops) to seize imperial power, particularly during crises when imperial authority was unstable and challenged. The situation in 193, after Pertinax died, clearly illustrates this. While Didius Iulianus was able to seize power in Rome by using his fortune to gain support of the praetorian guard, his most important rivals were three provincial governors: Pescennius Niger in Syria, Clodius Albinus in Britannia and Septimius Severus in Pannonia Superior. Because the latter had the support of more troops than the others, he won the imperial throne. Moreover, having himself used his position as governorcommander to seize the Principate, Severus realized the danger should an individual governor control too large a military force, so it can hardly be coincidental that the provinces of his former rivals were subdivided into two during or not long after Severus' reign. ${ }^{83}$

Moreover, senators were deployed as troubleshooters, serving as generals of special army detachments drawn from the legions. Such generals (mostly duces or occasionally praepositi) were linked to these detachments for a specific purpose, a particular military expedition. If proven successful, a general and his field army could be put into action at other campaigns as well. Although Severus sent a provincial governor to remedy at least one military crisis (Virius Lupus against Albinus), he usually sent men from outside the province to solve military crises. Occasionally, especially in his earlier campaigns, Severus chose senators from senatorial families who were in the more advanced (consular) stage of their careers as generals, such as Anullinus. The support of such men may helped legitimatize his position toward senators in his early reign. On the other hand, senators of lower rank, most of them homines novi, also commanded considerable forces in critical times. ${ }^{84}$ Marius Maximus and Septimius Castinus were mere legati legionis before they were made

${ }^{83}$ As mentioned above, Syria was divided into Syria Phoenice and Syria Coele in 193. The exact date of the subdivision of Britannia into Britannia Inferior and Britannia Superior, which Herodianus 3, 8, 2, places ca. 197/198, is heavily disputed. Graham (1966), 97-107, however, convincingly argues that the division must have occurred after Severus' death in 211, probably under Caracalla ca. 213/214. On the discussion, see Birley (2005), 333-336, with further references.

${ }^{84}$ Another provincial governor who may have played a role in Severus' battle against Albinus was Geta, but as he was Severus' brother, deploying him did not involve too much risk. 
duces. Candidus and Claudianus were also of praetorian rank at the time of their (first) generalships.

Other senators had commissions as advisers (comites) in the imperial entourage during campaigns. Under Severus, this group also contained senators who had little or no military experience, but who could nonetheless contribute to the campaign. Their wealth, their status and influence (particularly in Rome) and of course their connections with other senators helped Severus strengthen his position, which the emperor obviously considered necessary at the beginning of his career. Hedius Rufus Lollianus Gentianus is a good example of such a senator, as well as Fabius Cilo, who was initially sent to Thracia to prevent Niger from advancing any further westward, but who in a wise move was transferred to the emperor's entourage after his defeat. Iunius Faustinus Placidus Postumianus and Iulius Avitus Alexianus, comites in Britannia, were of a different order, as they had gained experience in the military and logistics of war.

Beneath the senatorial generals operated a group of lower commanders, primarily equites. Valerius Valerianus, for instance, was as equestrian commander (praepositus) subordinate to Anullinus. The same seems to have applied to Avitus Alexianus, who operated under Fabius Cilo in Moesia Superior circa 195. Oclatinius Adventus, who may have been sent to Britannia with a special task in preparing Severus' expedition, was perhaps not subordinate to Alfenus Senecio. On the other hand, in view of the obscurity of his exact range of duties and his extraordinary career, he may not have been representative of the position of equites involved in the military under Severus.

As said above, Severus sought senatorial support at the beginning of his career, but some senatorial generals, especially senators from senatorial families, served only sporadically in military events and were then transferred to positions of a more civil-administrative nature. Severus thus made sure that those men whose status and connections gave them easy access to money and senatorial support were not given too many troops, since a concentration of military power under any of them would increase the danger of a coup. ${ }^{85}$ Other military officers saw action more

${ }^{85}$ Cf. HA, Vita Sev. 15, 4-6: ' $\ldots$ he even went so far as to bring charges against several of his own friends on the ground that they were plotting to kill him. He put numerous others to death on the charge of having asked Chaldeans or soothsayers how long he was destined to live; and he was especially suspicious of anyone who seemed qualified for the imperial power ...' 
often, since Severus obviously needed capable generals as long as he had not ended the civil and Parthian wars. Whatever happened exactly will always be unclear, but after the incident with Laetus, Severus seems to have exercised more restraint in his attitude toward his (former) generals, even those who were homines novi. Most of them were granted consular rank and were appointed consular governor once or twice before their careers were (temporarily) stopped. Others' careers ended abruptly immediately after 198 . Some generals served again in civil-administrative posts under Caracalla. It is striking, however, that these former generals were never again commissioned in times of war, not even by Severus during his campaign in Britannia. Severus thus made sure that none of his high-ranking military officers was able to combine high senatorial status and military power and become a threat to his imperial authority. The trend toward replacing senatorial officers, legionary commanders and governors of military provinces with equestrian officers, who were appointed agens vice praesidis or agens vice legati legionis, which started from 200 onward, should perhaps also be seen in this perspective.

In sum, when Severus claimed the imperial throne, his power was essentially based on the support of the legions stationed in the Rhine and Danube area. During the wars in the first years of his reign, Severus depended much on his military officers. At that point, he tried to strengthen his position by seeking support among the senatorial elite. The combination of their high status and some experience in military offices made them suitable candidates for posts as military officers. Alongside them, other senators, who had gained more experience in the military sphere, especially homines novi, but who could not compete in status with the senatorial elite, were also appointed as high-ranking military officers. Militarily skilled equites were appointed as senatorial generals' subordinates. Only rarely did they have final responsibility in military crises. Between 198 and 208, however, when the Empire was at peace, Severus was able himself to dispose of those men who could pose a threat to his position: some were promoted to high civil-administrative posts; others disappeared from our view, permanently or temporarily. A few years later, when Severus needed military officers for his British expedition, none of his former generals of the civil and Parthian wars went into action again. 


\subsection{Gallienus and His Military Officers}

In 253, Valerianus was proclaimed emperor. In the same year, he made his son Gallienus co-emperor. Gallienus became the Empire's sole ruler when Valerianus was captured by the Persians in 260, the first time that the Empire had experienced the humiliation of a ruler falling into hostile hands. The consequences manifested themselves immediately: while barbaric tribes invaded the border regions continually, usurpers emerged in both the East and the West.

The Beginning of Gallienus' Sole Reign: The West (260-262)

Table 4.6. Men involved in military events in the West (260-262)

\begin{tabular}{ll} 
Name & Position \\
\hline Aureolus & Dux equitum 260/268 \\
Claudius (II Gothicus) & Dux ?? ca. 262? \\
Ingenuus & Senior commander $(d u x)$ of (vexillationes of) the \\
& Pannonian (and Moesian) legions (governor?) \\
& $253 / 260$ \\
Postumus & Officer (dux?) in command of (vexillationes) of Rhine \\
& legions (or governor of Germania Inf.)260 \\
Regalianus & Dux (or governor?) in Illyricum $(253 / 260)$ \\
\hline
\end{tabular}

When the news of Valerianus' capture reached the West, Germanic tribes had already penetrated the Rhine border and seized the Agri Decumates (the area between the Rhine and the Neckar). Gallienus probably was in or near Milan fighting the Iuthungi, who had by then invaded northern Italy ${ }^{86}$ Gallienus finally defeated the Germanic invaders in midsummer $\mathrm{AD} 260$. But probably at the same time a certain Ingenuus, whose origins and early career are a mystery to us, headed a revolt against Gallienus in Pannonia. ${ }^{87}$ Ingenuus' office at the time of his rebellion cannot be determined with certainty. According to the sources, he 'governed' (Lat: regebat) or 'took care of' (Lat: curans) the Pannonian provinces or

${ }^{86}$ Sources for the invasions in the West: Aurelius Victor, Liber de Caesaribus 33, 3; Zosimus 1, 37; Zonaras 12, 24; Eutropius 9, 8; Orosius 7, 22, 7. See Potter (2004), 256257; Drinkwater (2007), 52-55, with further references.

87 Aurelius Victor, Liber de Caesaribus 33, 2 called him Ingebus. Orosius 7, 22, 10 called him Genuus. In most souces, however, he is called Ingenuus. On Ingenuus, see $P I R^{2}$ I 23; PLRE I, Ingenuus 1, Bleckmann (1992), 226-237, Johne-Hartmann-Gerhardt (2008), 1162-1163, with further references. 
legions. ${ }^{88}$ The Historia Augusta reports that Ingenuus was proclaimed emperor by the Moesian legions. In that case, it is more likely that Ingenuus was a $d u x$ who held the command over (vexillationes in) the Pannonian and Moesian legions than a provincial governor of several Illyrian provinces ${ }^{89}$ This conjecture finds support in the parallels of appointments in those days in Illyricum. The date of Ingenuus' usurpation has been heavily disputed, because of unclear literary sources. Nowadays it is assumed that it took place in 260, in reaction to Valerianus' defeat and capture..$^{90}$ It has been suggested that Ingenuus was supervisor of Gallienus' son Valerianus and that Ingenuus' position became insecure after Valerianus II died in 258. Although this may have been an additional motive for the usurpation, this hypothesis lacks confirming evidence. ${ }^{91}$

As Gallienus found himself in the middle of a campaign against the Iuthungi, he sent Aureolus to solve the situation in Pannonia. The Historia Augusta reports that Aureolus, allegedly a man of humble birth from Dacia, served in the army under Valerianus. ${ }^{92}$ By 260 , he seems to have risen to the position of cavalry commander, in which capacity he fought against the usurper Ingenuus. ${ }^{93}$ Using the advantage of the mobility of

${ }^{88}$ HA, Vita Trig. Tyr. 9, 1: 'qui Pannonias tunc regebat'; Aurelius Victor, Liber de Caesaribus 33, 2: 'curans Pannonos'.

${ }^{89}$ Cf. Goltz-Hartmann (2008), 242; 262-263, who assume that Ingenuus held a 'provinzübergreifenden Sonderkommando in beiden pannonischen und wohl auch moesischen Provinzen'. Luther (2008), 326-327, however, considers Ingenuus governor of the Pannonian and Moesian provinces.

${ }^{90}$ If we may believe HA, Vita Trig. Tyr. 9, 1, Ingenuus was proclaimed emperor in the consulship of Tuscus and Bassus, AD 258. Aurelius Victor, Liber de Caesaribus 33, 2, and Zonaras 12, 24, on the other hand, date the revolt after the capture of Valerianus in AD 260. Fitz (1966c) has argued that the revolt should be dated in 258 . This date was accepted by De Blois (1976), 4. However, more recently, Drinkwater (1987), 104-105, and Potter (1990), 52, have argued convincingly that the revolt should be dated in 260 . That the date is still debateable, however, follows from propositions referred to in Drinkwater (2007), 54-55, to date the revolt mid-259 into early 260. Cf. Goltz-Hartmann (2008), 262-263, note 203 , with further references.

${ }^{91}$ See Fitz (1966c), 26-28; Drinkwater (1987), 22; 103; Bleckmann (1992), 226-227, with further references.

92 On Aureolus' humble birth and Dacian origins, see Syncellus 717 (Mosshammer (1984), p. 467). Cf. De Blois (1976), 43: 'According to the romanticised account given by Zonaras $(12,24)$ Aureolus was a Getan shepherd. He entered the army, distinguished himself in the stables and ended up as Gallienus' cavalry commander.' On Aureolus entering the army under Valerianus: HA, Vita Trig. Tyr. 10, 14.

93 Aureolus as general in Illyricum: HA, Vita Gall. 2, 6; 3, 3; Trig. Tyr. 11, 1; Aureolus as cavalry commander: Zosimus 1, 40, 1 (

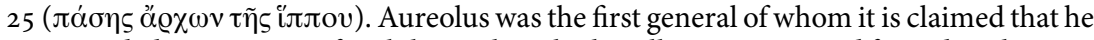
commanded a new corps of mobile cavalry which Gallienus composed from detachments 
the cavalry, Aureolus defeated Ingenuus at Mursa (Pannonia Inferior). ${ }^{94}$ Ingenuus then took his own life or was killed by his attendant soldiers during his flight. ${ }^{95}$

Ingenuus' defeat did not end the problems in Illyricum, for Danubian troops proclaimed Regalianus emperor against Gallienus in Moesia. ${ }^{96}$ The Historia Augusta claims that Regalianus was of Dacian origin and that he had been made dux Illyrici by Valerianus. ${ }^{97}$ Some scholars thought he was a senator, asserting that he was the governor of several senatorial Illyrian provinces (Moesia, Pannonia Superior). Against this, several other scholars suggest that he was sent to Illyricum as military $d u x$ and not as governor. This view, according to which he was not necessarily of senatorial rank is just as plausible, if not far more likely. ${ }^{98}$

It is unclear to what extent Regalianus was involved in Ingenuus' revolt. If we are to believe Aurelius Victor, Regalianus gathered the survivors of Ingenuus' coup and continued the latter's rebellion. ${ }^{99}$ As both of them operated in the same area, it is unlikely that Regalianus was unaware of Ingenuus' revolt. Even if he did not support or actively interfere in it, he may have given Gallienus the idea that he did by avoiding any serious attempt to put the rebellion down. If so, he had no other choice than to claim the imperial throne for himself after Ingenuus' defeat.

and rearrangements of the cavalry of legions. Aureolus is referred to and described as hipparchos, but no official terminology is being used to describe the position, as Simon (1980), 437, points out. On Aureolus as a general of a new corps of mobile cavalry, see Paschoud (1996), 108. On Gallienus' cavalry reforms, see also Simon (1980), 435-452; Bleckmann (1992), 226-237. On Aureolus' role in Ingenuus' defeat, see Zonaras 12, 24; cf. Bleckmann (1992), 227-228; Goltz-Hartmann (2008), 263.

${ }^{94}$ On Ingenuus' defeat, see HA, Vita Trig. Tyr. 9; Aurelius Victor, Liber de Caesaribus 33, 2; Eutropius 9, 8; Zonaras 12, 24.

${ }_{95}$ HA, Vita Trig. Tyr. 9, 4, claims that Ingenuus committed suicide. Zonaras, 12, 24, claims that he was killed by his soldiers. The fact that Ingenuus issued no coins, indicates that he reigned for only a short time.

${ }^{96}$ On Regalianus, see PIR ${ }^{2} \mathrm{R}$ 36; PLRE I, Regalianus, and Bleckmann (1992), 237-239; Johne-Hartmann-Gerhardt (2008), 1163, with further references. On Regalianus' revolt, see HA, Vita Trig. Tyr. 10; Epitome de Caesaribus 32, 3.

97 Dacian origin is claimed by HA, Vita Trig. Tyr. 10, 8, which also asserts that Regalianus was a kinsman of Decebalus, the king of Dacians whom Traianus defeated in 107, which is very questionable. On Regalianus position as dux Illyrici: HA, Vita Trig. Tyr. 10, $1 ; 10,9$.

98 Scholars who assume that Regalianus was a senatorial governor are Barbieri (1952), 307, no. 1712; Degrassi (1952), 71; Thomasson (1972-1990), 108; 130; Goltz-Hartmann (2008), 264; Heil (2008a), 723, note 36, with further references. For the view that Regalianus was a military $d u x$, see $R E$ 5, $1869 \mathrm{ff}$., based on HA, Vita Trig. Tyr. 10, 8: 'vir in $\langle r e\rangle$ militari semper probatus'; cf. Christol (1986), 147-149. Cf. $P I R^{2} \mathrm{R} 36$, with further references.

99 Aurelius Victor, Liber de Caesaribus 33, 2. 
Regalianus fought successfully against the Sarmatae, who threatened the Danubian provinces, but was defeated not much later. According to the Historia Augusta, a coalition of the Roxolani (a Sarmatic tribe) with help from his own soldiers and with provincials who feared Gallienus' reprisals, killed him. ${ }^{100}$ As Gallienus was still dealing with the Iunthungi in Italy at that time, the emperor seems to have been unable to deal with Regalianus' rebellion himself. Although none of our sources says so, some have assumed that Aureolus was involved in Regalianus' defeat. ${ }^{101}$ Either way, Regalianus' revolt appears to have been neither lasting nor widespread. ${ }^{102}$

In an attempt to end invasions of tribes from outside the Empire in the Rhine and Danube area, Gallienus forged treaties with local kings. When Gallienus fought barbarian tribes on the Rhine, he eventually won the upper hand by making peace with a Germanic king who thereafter guarded the Rhine frontier in Gallia. ${ }^{103}$ Unfortunately, little is known about the exact circumstances of this agreement. We are better informed on a pact Gallienus struck with Attalus, king of the Marcomanni, on the middle Danube. The Marcomanni had invaded Pannonia in 254. It was probably around 258 that Gallienus came to an alliance with Attalus, allowing the Marcomanni to settle in Pannonia. Although the hostile senatorial sources accused Gallienus of doing this to win Attalus' daughter Pipa as a concubine, the pact makes more sense as an attempt to outsource the defense of parts of the frontier regions into foreign hands. Speidel argues that the Marcomanni not only served as border guards but also as mobile elite forces, high-ranking units of the imperial field army, with their king, rather than Roman officers, in command. ${ }^{104}$

${ }^{100}$ HA, Vita Trig. Tyr. 10, 1-2. Cf. Aurelius Victor, Liber de Caesaribus 33, 2; Eutropius $9,8,1$, in which Gallienus (i.e. Aureolus?) is mentioned as Ingenuus' killer. The account of the Historia Augusta was accepted by several scholars. See Fitz (1966c), 58-63; Drinkwater (1987), 105. On Gallienus fighting against the Alamanni at the same time, see Halfmann (1986), 237; Drinkwater (2007), 54-55.

101 See Saria (1937); Fitz (1966c); Alföldi (1967), $101 \mathrm{f}$.

102 The small number of coins struck by Regalianus suggests that his reign was very short. Furthermore, all the coinage of Regalianus and his wife were struck over other old coins, and the only mint to issue coins for them was the mint of Carnuntum (Pannonia), which seems to have been the center of Regalianus' revolt. HA, Vita Gall. 9, 1, suggests that Regalianus was still in power in 263 , but this seems incorrect: see $P I R^{2} \mathrm{R} 36$, with further references.

103 Zosimus 1, 30.

104 On Gallienus' treaty with the Marcomanni, see Epitome de Caesaribus 33, 1; Speidel (2006), 73-76. On Germanic kings as Roman army tribunes, see id. (2006), 75, note 14, with further references. 
Despite all these efforts, Gallienus' authority was not restored completely in the West. He was faced with one more usurper, who would accomplish segregation within the western part of the Empire: Cassianius Latinius Postumus. ${ }^{105}$ During the revolt of Ingenuus, Gallienus put Postumus in charge of the armies guarding Gallia and the Rhine area, perhaps as $d u x$ or governor, but his exact position cannot be determined. ${ }^{106}$ Apparently, Postumus' troops were displeased for some reason and decided to rebel. They proclaimed their commander emperor, probably in the spring or early summer of $260 .{ }^{107}$ Postumus and his troops marched on Cologne and besieged the city, in which Gallienus' son Saloninus and his guardian Silvanus had their headquarters. ${ }^{108}$ Even-

${ }^{105}$ His full name can be found in several inscriptions, for instance, CIL $2.4943=$ ILS 562 (Hispania Citerior);13.8879; 8882-8883; 9855-9856; 8972, $9023=$ ILS 561 (Lugdunensis), $A E$ 1924, 1 (Britannia); $A E$ 1958, 58 (Aquitania). Epitome de Caesaribus 32, 3, calls him Cassius Labienus Postumus.

${ }^{106}$ HA, Vita Trig. Tyr. 3,9 ('Transrhenani limitis dux et Galliae praeses'), Zosimus 1, 38, 2 ('barbaris per Galliam praesidebat'), Zonaras 12, 24. Perhaps Postumus was dux ripae or dux limitis, or praeses or senatorial legatus in Germania Inferior, as Drinkwater (1987), 25-26, and Eck (1985), 222-224, suggest. Eck (2004), 561-562, however, asserts that Postumus was 'ritterlicher Ambtsträger mit einem umfassenden militärischen Aufgabenbereich'. See Johne-Hartmann-Gerhardt (2008), 1126, summing up all the suggestions, with further references. According to Eutropius 9, 9, 1, Postumus was of humble origin. The epigraphic and numismatic evidence suggest that Postumus had been awarded ornamenta consularia before his usurpation, which would point to high standing at the imperial court of Gallienus. See König (1981), 52; 66. Postumus must also have been superior to M. Simplicinius Genialis, vir perfectissimus, agens vice praesidis, commanding soldiers of the province of Rhaetia, Germany, and by the militia, who is mentioned in $A E$ 1993, 1231 (Augsburg). See Potter (2004), 256.

107 HA, Vita Trig. Tyr. 3, 2-4; Gall. 4, 3; Zosimus 1, 38, 2; Aurelius Victor, Liber de Caesaribus 33, 8; Epitome de Caesaribus 32, 3; Eutropius 9, 9. The date of Postumus' revolt is highly disputed. Currently it is generally assumed that it took place in AD 260, between May and July. See Potter (2004), 256-257, who quotes the inscription found in Augsburg (AE 1993, 1231); cf. König (1981), 4-19; Drinkwater (1987), 95-102; Strobel (1993), 245; Jehne (1996).

108 According to Zosimus 1, 38, 2 and Zonaras 12, 24, Silvanus (called Albanus by Zonaras), was entrusted with the care of Gallienus' son Saloninus, while Postumus was left in command of the Rhine frontier. HA, Vita Trig. Tyr. 3, 1, claims that Postumus was entrusted with the care of Saloninus, but has probably mistaken him for Silvanus. See Bleckmann (1992), 245. It has been suggested that Silvanus was praefectus praetorio in 260. Howe (1942), 81, no. 50; König (1981), 47, posits that Silvanus merely carried out the civil duties of the praetorian prefect and that the tension between Postumus and Silvanus was caused by tension between bureaucracy and the military. According to Bleckmann (1992), 246, note 101, such a sharp division between the military and bureaucracy was unlikely during the reign of Gallienus. Allegedly, a quarrel between Postumus and Silvanus over the distribution of booty taken from barbarians caused the rebellion. On this matter, see Zon. 12, 24; Bleckmann (1992), 242-248, with further references. 
tually, the garrison of Cologne handed these two members of Gallienus' familia over to Postumus and they were put to death. Postumus became the first emperor of the so-called 'Gallic empire'; he controlled not only the provinces of the Rhineland, but also the inland provinces of Gallia (except Narbonensis) and Britannia. ${ }^{109}$

When Postumus seized power, Gallienus was finishing his campaign against the Alamanni, followed by a stay in Rome. His successful general Aureolus was restoring Gallienus' authority in the East, after the Macriani had seized power (see below). Although there are indications that Aureolus was sent against Postumus in 262, the available literary evidence is downright confusing. The Historia Augusta claims that Aureolus seized imperial power around 262, after the defeat of the Macriani, but also records that Aureolus joined Gallienus not much later in an attempt to overthrow Postumus; these two claims seem to rule each other out. ${ }^{110}$ According to the Historia Augusta, however, Gallienus reconciled with Aureolus after his attempt to seize power. ${ }^{111}$ The date of this campaign against Postumus, in which Gallienus seems to have recaptured Raetia, is highly disputed; it may have taken place later in Gallienus' reign. ${ }^{112}$

The Historia Augusta claims that another man was involved as dux in Gallienus' campaign against Postumus: Aurelius Claudius, better known as the emperor Claudius II Gothicus. ${ }^{113}$ Claudius was allegedly born in Illyricum during Caracalla's reign. ${ }^{114}$ References to Claudius' early career

109 According to Drinkwater (1987), 27-28; $116 \mathrm{ff}$., Postumus gained control over the entire west soon after the summer of AD 260, well before 261 . There is no evidence that Postumus actually intended to create a separate imperium. Only Eutropius 9, 9, 3, mentions a Galliarum imperium. In his propaganda, Postumus placed himself in the tradition of the emperors of the central Empire, and his administration was patterned after the central Empire.

110 On Aureolus' imperial acclamation, see HA, Vita Gall. 2, 6; 3, 1; Tyr. Trig. 11, 1; 12, $2 ; 12,14 ; 18,1 ; 18,3$. On Aureolus fighting Postumus and the reconciliation, see HA, Vita Gall. 4, 6; 7, 1; 21, 5; Tyr. Trig. 11, 3; Aurel. 16, 1.

111 The possibility that the author of the Historia Augusta confused the situation and Aureolus' imperial acclamation in 268 with the course of events in this previous campaign against Postumus should not be ruled out. On this matter, see Alföldi (1967), 2-3; Bleckmann (1992), 248-251; 254-255; Paschoud (1996), 108.

112 See Goltz-Hartmann (2008), 274, note 240, supplying further references on the suggested dates for this campaign. They date it ca. 266-267. Gallienus was allegedly wounded in the battle against Postumus, see HA, Gall. 4, 4-6; Trig. Tyr.3, 5; Zonaras 12, 23.

113 HA, Vita Gall. 7, 1. Cf. Goltz-Hartmann (2008), 274, note 239.

${ }_{114}$ HA, Vita Claud., 11, 9, claims that Claudius was of Dalmatian or Dardanic orgin. Cf. HA, Vita Claud. 14, 2: 'Illyricianae gentis vir'. The information may have been invented by the Historia Augusta's author. The claims that Claudius was the son of a Gordianus (Epitome de Caesaribus 34, 1) and that he was related to Probus (HA, Vita Prob. 3, 2- 
can be found in letters attributed to Decius, Valerianus and Gallienus in the Historia Augusta, which are generally considered fictitious. According to these letters, Claudius served several tenures as tribunus and was made general of Illyricum (dux totius Illyrici) by Valerianus, commanding the armies of Thracia, Moesia, Dalmatia, Pannonia and Dacia. The posts, like the letters, were probably inventions. ${ }^{115}$ However, it is not unlikely that Claudius had served in the army for quite some time, beginning no later than Gallienus' reign. ${ }^{116}$

Whether an attempt to regain the Gallic part of the Empire was made in 262 or not remains uncertain. What can be concluded is that any possible attempts were unsuccessful: for the time being, the Gallic empire continued to exist.

The Beginning of Gallienus' Sole Reign: Meanwhile in the East (260-262)

Table 4.7. Men involved in military events in the East (260-262)

\begin{tabular}{|c|c|}
\hline Name & Position \\
\hline Aureolus & Dux equitum $260 / 268$ \\
\hline Ballista & $\begin{array}{l}\text { Praefectus praetorio or dux under Valerianus } \\
\text { Praefectus praetorio under the Macriani }\end{array}$ \\
\hline Domitianus & Dux under Aureolus 261 \\
\hline Fulvius Macrianus & $\begin{array}{l}\text { Procurator arcae et praepositus annonae during } \\
\text { Valerianus' Persian campaign } 259 / 260\end{array}$ \\
\hline Memor & In charge of Egypt's corn supply 262 \\
\hline Mussius Aemilianus & Praefectus Aegypti 260-261 \\
\hline Septimius Odaenathus & $\begin{array}{l}\text { Exarchos of Palmyra } 250 \text { s } \\
\text { Governor of Syria Phoenice? } 258\end{array}$ \\
\hline & $\begin{array}{l}\text { Troubleshooter in the East (dux Romanorum and } \\
\text { corrector/rector Orientis) from } 260 / 261 \text { onward }\end{array}$ \\
\hline Theodotus & $\begin{array}{l}\text { Dux commanding a fleet and troops } 261-262 \\
\text { Praefectus Aegypti } 262-263\end{array}$ \\
\hline Valens & $\begin{array}{l}\text { Proconsul Achaiae and/or military commander in } \\
\text { Macedonia } 260 / 261\end{array}$ \\
\hline
\end{tabular}

4), are generally considered fictitious, as well as his connection to Constantius Chlorus, which was made public only in the panegyric of 310 (HA, Vita Claud. 13, 1-3; Pan. Lat. 6, 2, 2, Panegyric of Constantius, ed. Mynors-Nixon-Rodgers (1994), 219-220; 573).

115 On this, see Damerau (1934), 21-24, and Syme (1971), 215-216. Cf. Hartmann (2008a), 298. If Claudius was indeed general in Illyricum, one would expect him to have been involved in the campaigns against Ingenuus and Regalianus as well. Yet, no mention of this is made in the sources.

${ }^{116}$ It is noteworthy that the fourth-century author of the Historia Augusta credited Valerianus with appointing Claudius as $d u x$ in Illyricum. Perhaps Illyricum acted as a 
After the Persians had captured Valerianus and while Gallienus was far away in the West, the eastern troops wanted to choose their own emperor. Two men, who had accompanied Valerianus on his Persian campaign, came to the fore: Ballista and Fulvius Macrianus. Ballista's office at the time of Valerianus' capture is uncertain. According to the Historia Augusta, Ballista was Valerianus' praefectus. Although the author does not specify the prefecture, it is generally assumed that he referred to Ballista as Valerianus' praetorian prefect. However, Ballista is also

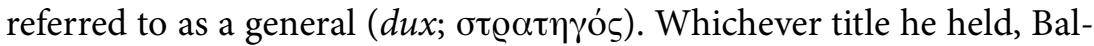
lista campaigned with success against the Persians during Valerianus' campaign. ${ }^{117}$

Fulvius Macrianus, as discussed in Chapter 3 (section 3.1), organized money and supplies for the army in the East during Valerianus' Persian expedition. According to Eusebius, Macrianus did not help Valerianus when he was captured by the Persians. ${ }^{118}$ Allegedly, Ballista immediately offered Macrianus the imperial throne. ${ }^{119}$ Macrianus had control over the imperial treasure and the army supplies in the East and thus had the most essential resources at his disposal. He was also able to mint coins. Furthermore, the support of Ballista, who had been successful against the Persians, would contribute to the legitimization of his claim for power. Nevertheless, Macrianus refused and suggested that his sons, Macrianus minor and Quietus, share the emperorship. They were proclaimed not long afterwards, their rule being accepted in the East including Egypt. ${ }^{120}$

transitional area between the territory under Gallienus' care in the West and Valerianus' territory in the East, where additional leadership was badly needed.

117 On Ballista as (praetorian) prefect, see HA, Vita Trig. Tyr. 12, 1. On Ballista as general, see HA, Vita Val. 4, 4; Zonaras 12, 23 (calling him Kallistos); Syncellus 716 (Mosshammer (1984), p. 466). The author of the Historia Augusta states (HA, Vita Tyr. Trig. 18, 12-13) that even as he was writing his account, the reports on Ballista were doubtful and inconsistent. On Ballista, see $P I R^{2}$ B 41; PLRE I, Ballista; GoltzHartmann (2008), 259-262. On Ballista as praetorian prefect under Valerianus, see Johne-Hartmann-Gerhardt (2008), 1073, PPO 14, with further references.

118 Eusebius, Historia Ecclesiastica 7, 23, 1.

119 HA, Vita Gall., 1, 2-3; Trig. Tyr., 12, 3-12; 14, 1.

120 On Macrianus maior's refusal and the reasons for it, see HA, Vita Gall. 1, 3; Tyr. Trig. 12, 12; Eusebius, Historia Ecclesiastica 7, 10, 8; Zonaras 12, 24; Continuator Dionis, Petrus Patricius, Excerpta de Sententiis, ed. Boissevain, p. 264, 159. HA, Vita Gall. 1, 3; Tyr. Trig. 12, 12, mentions that Macrianus became emperor together with his sons, but seems to be mistaken. The report in HA, Vita Tyr. Trig. 12, 10, that the sons of Macrianus had both served as military tribunes under Valerianus, is probably fictitious. On the Macriani, see PIR ${ }^{2}$ F 546; PLRE I, Macrianus 2; Macrianus 3; $P I R^{2}$ F 547; PLRE I, Quietus 1. See Goltz-Hartmann (2008), 260, note 195, with further references, and 261, note 196, with references on where their rule was accepted. 
Ballista was sent to Asia Minor, where he triumphed over the Persians again. Then he returned to Syria, where he became praetorian prefect of the Macriani. ${ }^{121}$ While Macrianus maior and Macrianus minor marched westwards to provoke a confrontation with Gallienus, Quietus and Ballista stayed in the East. Since Gallienus was at that time dealing with a raid of Iuthungi in northern Italy, he sent Aureolus in response to their provocation. Aureolus' dux Domitianus finally defeated the Macriani at the Balkans in the summer or autumn of 261. The unsuccessful emperors were then killed by their own soldiers. ${ }^{122}$

After his father and brother had been defeated in Illyricum, Quietus lost control in the East, while another man gained power: Septimius Odaenathus. ${ }^{123}$ Odaenathus was born circa 220 in Palmyra, which was by that time a colonia within the Roman Empire. ${ }^{124} \mathrm{He}$ seems to have been from a noble Palmyran family. ${ }^{125}$ The name Septimius may indicate that Odaenathus' family had received Roman citizenship under one of the Severan emperors. In that case it is likely that Odaenathus' family was a leading kin in Palmyra since about the beginning of the third century. ${ }^{126}$ Little is known about Odaenathus' career before Valerianus' capture. In the early 250s, Odaenathus was promoted to exarchos (' ' $^{\prime} \propto \varrho \chi 05$, 'chief') of Palmyra. ${ }^{127}$ In this position, Odaenathus had full military authority, which enabled him to reinforce the troops of Palmyra. ${ }^{128}$ At about the same time, he was granted senatorial status, which promoted him from the local Palmyran elite into the imperial elite ('Reichsaristokratie') and

121 Ballista as praetorian prefect of the Macriani, see HA, Vita Gall., 3, 2; Trig. Tyr., 14, 1; 18, 13. Zonaras 12, 24, refers to him as cavalry commander (i $\pi$ (i) $\chi 0 \varsigma$ ).

${ }^{122}$ HA, Vita Gall. 2, 5-7; 3, 1; Tyr. Trig. 11, 1-2; 12, 12-14; Zonaras 12, 24. On Domitianus (PIR D 114) as dux Aureoli, see HA, Vita Gall. 2, 6; Trig. Tyr. 12, 14; 13, 3 .

123 On Odaenathus, see $P I R^{2}$ S 472; PLRE I, Odaenathus. On his career, see Hartmann (2001), $86 \mathrm{ff}$, and Hartmann (2008c), 346-351, with further references.

124 Millar (1990), 42-46.

125 According to Zosimus 1, 39, 1, Septimius Odaenathus was highly esteemed because the emperors had honored his ancestors. A group of bilingual inscriptions (Palmyrene Aramaic and Greek) render Odaenathus' ascendants. See Gawlikowski (1985).

126 Hartmann (2001), 88-90, suggests that Roman citizenship was bestowed upon the family in the mid-second century. He acknowledges, however, the importance of the family at the beginning of the third century.

127 Gawlikowski (1985), 257 n. $13=$ SEG 35, $1497=38,1580$.

128 On the military connotations of the title exarchos, see Hartmann (2001), 92-94. Potter (1990), 389, also suggests that the title reflected Odaenathus' command of the Palmyrene militia. Eventually, Odaenathus' son Hairan was also given the title exarchos, which turned the position into a heriditary post. See Hartmann (2001), 102. 
enabled him to occupy positions in the imperial service. ${ }^{129}$ By granting him senatorial status, Rome supported Odaenathus' ascent. Circa 257 / 8, Odaenathus became vir consularis, either by holding an actual suffect consulship, by being accepted inter consulares, or by being granted ornamenta consularia. ${ }^{130}$ Inscriptions which can be dated around 258, call

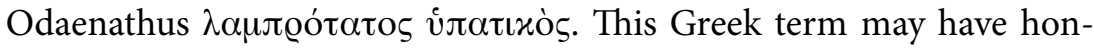
ored Odaenathus for reaching consular rank, as Potter argues, but can also indicate that Odaenathus was governor of Syria Phoenice at that point. ${ }^{131}$

After Ballista had defeated the Persians at Cilicia in the summer of 260, Odaenathus attacked them at the Euphrates, while they were retreating, after which they withdrew from Roman territory. ${ }^{132}$ Ballista and Quietus retreated to Emesa, where they heard the news of Macrianus maior's and minor's deaths. Then, the city's inhabitants killed Quietus in the autumn of 261. It remains unclear whether Ballista instigated this or whether Odaenathus played a role. ${ }^{133}$ Ballista himself was probably killed soon afterwards by Odaenathus. ${ }^{134}$ In 260 , Gallienus gave Odaenathus an official position as troubleshooter in the East. Although his exact titles are not directly attested, it has been suggested that he was made $d u x$ Romanorum after his victory over the Persians and then corrector totius Orientis after Quietus' defeat. In that way, he united the highest available

${ }^{129}$ Hartmann (2001), 97, claims that Odaenathus was accepted into the senate through adlectio.

${ }^{130}$ IGRR 3, 1031 (Palmyra). Potter (1990), 389-390, argues for merely honorific ornamenta consularia. Hartmann (2001), 104-105, argues for a position as consul suffectus in absentia. Cf. Hartmann (2001), 104, note 167, with further references.

131 The term hypatikos (i் ${ }^{1} \alpha \tau i x \mathrm{o}_{\zeta}$ ) was used for the governor of the province of Syria since the second century. A Tyrian text has been taken to show that Odaenathus' title

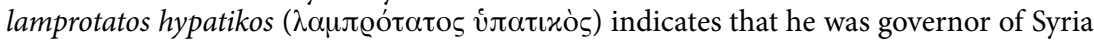
Phoenice, probably in 258. According to Potter (1990), 389-390, ton lamprotat(on) ( $\lambda \alpha \mu \pi \varrho \tau_{\alpha} \tau \mathrm{\tau}$ ) can easily be interpreted to mean no more than ho lamprotatos sunkletikos

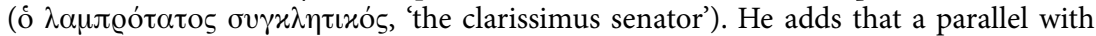
Abgar IX offers the possibility that Odaenathus was given the ornamenta consularia. Millar (1993), 165, implies that Odaenathus might have held the governorship, possibly enhanced by separate consular honors. Hartmann (2001), 105-108, considers serious the possibility that Odaenathus was governor of Syria Phoenice.

132 On the lines of march of Ballista and Odaenathus, see Kettenhofen (1982), 106113. Cf. Goltz-Hartmann (2008), 259, with further references. Hartmann (2001), 106, uses Odaenathus' command over Roman legions in 260 to support his assertion of Odaenathus' governorship of Syria Phoenice and consequent membership in Roman administration at that time.

133 On Quietus' death, see HA, Vita Gall. 3, 1-5; Trig. Tyr. 15, 4; 18, 1; Zonaras 12, 24; Continuator Dionis, Petrus Patricius, Excerpta de Sententiis, ed. Boissevain, p. 266, 167.

${ }^{134}$ HA, Vita Tyr. Trig. 14, 1; 18, 1-3; Zonaras 12, 24. 
military and civil power in the area and he was thus de facto ruling the East. ${ }^{135}$ Apparently, Gallienus accepted Odaenathus' military authority in the East, and even rewarded him with extraordinary Roman honors to encourage continuing allegiance and further support.

As said above, Egypt accepted the rule of the Macriani. Coins struck by Macrianus and Quietus in Alexandria show that the praefectus Aegypti Mussius Aemilianus, whose career is discussed in Chapter 3 (section 3.1), had supported the rival emperors. After the Macriani were overthrown, Mussius Aemilianus was proclaimed emperor himself and stopped the grain supply to Rome late 261 . He probably had no other choice than to rebel himself after he had backed the wrong party. ${ }^{136}$ The fleet and troops sent by Gallienus under the command of dux Aurelius Theodotus soon overthrew Mussius Aemilianus. Theodotus captured Aemilianus and sent him to Gallienus. ${ }^{137}$ Another rebel arose in the East after Aemilianus' defeat: Memor, who was of Moorish origin, was in charge of the corn supply in Egypt. Allegedly, Theodotus and his men killed Memor before he was proclaimed imperator. ${ }^{138}$ Subsequently, Theodotus was appointed praefectus Aegypti by Gallienus, circa July/September 262. ${ }^{139}$

Supposedly, the provinces of Achaia and Macedonia also became involved somehow in the struggle between Gallienus and the Macriani. According to the Historia Augusta, the Macriani, preparing their expedition to the Balkans, ordered a consular senator named Piso (with the nickname 'Frugi') to depose Valens from his commission. Although Valens is attested as proconsul of Achaia, it is more likely that he (also)

135 Syncellus 716 (Mosshammer 1984), pp. 466-467, dates the appointment after Odaenathus' initial success against the Persians; Zonaras 12, 24, after he had suppressed Quietus and Ballista. On the suggestion that Odaenathus was dux Romanorum and then corrector totius Orientis, see Hartmann (2008c), 351-352, basing this position on the titles used by Vaballathus, Odaenathus' son. Potter (1990), 391-392, however, argues that Vaballathus must have had a different title than Odaenathus. He suggests that this title should be translated restitutor rather than corrector.

136 On Mussius Aemilianus signo Aegippius, see PIR ${ }^{2}$ M 757; PLRE I, Aemilianus 6. On his revolt, see HA, Vita Gall. 4, 1-2; Trig. Tyr. 22; Epitome de Caesaribus 32, 4. See Goltz-Hartmann (2008), 266-267, with further references.

137 On Aemilianus' death, see HA, Vita Gall. 4, 2; Trig. Tyr. 22, 8. On Theodotus, see PIR ${ }^{2}$ A 1617; PLRE I, Theodotus 4. On Theodotus as dux, see HA, Vita Gall. 4, 2; Trig. Tyr. 22, 8-10; 26, 4. See Goltz-Hartmann (2008), 268, with further references in note 218.

138 On Memor, see PIR ${ }^{2}$ M 490; PLRE I, Memor. On his usurpation, see Zosimus 1, 38, 1; Continuator Dionis, Petrus Patricius, Excerpta de Sententiis, ed. Boissevain, p. 264, 16o. See also Goltz-Hartmann (2008), 268-269, with further references.

139 Theodotus is attested as praefectus Aegypti from July/September 262, on P. Strassb. 1 , 5; cf. P. Oxy.17, 2107; 12, 1467. On Theodotus as prefect of Egypt, see Johne-HartmannGerhardt (2008), 1085, Aeg. 14, with further references. 
had a military command in Macedonia right then, as Gallienus must have taken measures to defend the Balkans against the advancing troops of the Macriani. That Valens is referred to as vir militaris in the Historia Augusta supports this hypothesis. ${ }^{140}$ Not much later, the soldiers proclaimed both Valens and Piso as (rival) emperors. Valens' troops soon killed Piso, and Valens did not survive his own soldiers much longer.

\section{Gallienus' Protectores}

\section{Table 4.8. Gallienus' protectores}

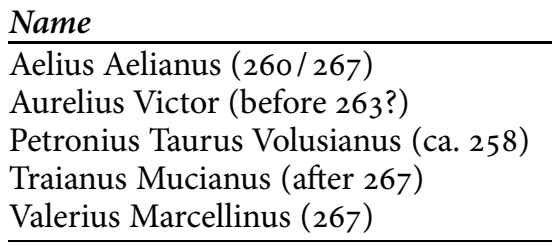

Several military officers under Gallienus received the title protector. The earliest attested example is Petronius Taurus Volusianus, whose career is rendered almost completely in an inscription from Etruria. ${ }^{141}$ As discussed in Chapter 3, Gallienus had promoted Volusianus from praefectus vigilum to praetorian prefect shortly after Valerianus' capture. Volusianus and the emperor were the consules ordinarii in 261 and it is likely that the prefect was in Rome, when Gallienus celebrated his Decennalia with a festival in the capital in 262. By then, the Etruscan Volusianus had gone through a pronounced military career, much of which was spent in Rome. ${ }^{142}$ After serving with the $V$ decuriae in the capital, Volusianus became centurio deputatus. In that capacity, he commanded troops detached from the provincial armies for special imperial service while the

140 On Piso and Valens, see HA, Vita Gall. 2, 1-4; Tyr. Trig. 19; 21; Ammianus Marcellinus 21, 16, 10; Epitome de Caesaribus 32, 4. Valens as vir militaris, see HA, Tyr. Trig. 19, 1. Allegedly Piso stem from the noble gens Calpurnia, a consular family which traced back its origins to the late Republic. Many scholars consider Piso as fictitious. Cf. PIR ${ }^{2} \mathrm{P} 428$; PLRE I, Piso 1, with further references.

141 CIL 11, 1836 = ILS 1332 (Arretrium, Italy). On Volusianus' career, see furthermore PIR P 313; PLRE I, Volusianus 6; Dobson (1978), 306-308, no. 215. See Goltz-Hartmann (2008), 279, note 254, for further references.

142 We must note that Volusianus' patronage of Arretium does not necessarily mean that he was born there. It does, however, indicate a strong connection to the region of Etruria. It is noteworthy that the Licinii, the gens from which Gallienus descended, were also of Etruscan origin. Dobson (1978), 306, mentions the lack of evidence to support the hypothesis that Volusianus was related to Valerianus and Gallienus. 
emperor was present in the capital. ${ }^{143}$ Next, Volusianus was promoted to the position of primuspilus in Germania Inferior. ${ }^{144} \mathrm{He}$ must somehow have caught Valerianus' or Gallienus' attention, as they appointed him praepositus equitum singularium, commander of the cavalry contingent which acted as imperial bodyguard. ${ }^{145} \mathrm{He}$ then served directly under Gallienus in the West for some years in the Danubian area, perhaps as commander in the imperial field army. ${ }^{146}$ Next, he was transferred to Rome where he became tribunus of a cohort of the Vigiles, a cohors urbana and a praetorian cohort, respectively. It was probably during his office as tribunus cohortis praetoriae, that Volusianus received the title protector. It is possible that by the time he held this post, a part of the praetorian guard was transferred to the Balkans to fight along with Gallienus. Volusianus' last position as military tribunus was thus not necessarily carried out in Rome. ${ }^{147}$ Then, he became praefectus vigilum, at a point usually dated circa $258 / 259$, and thus praetorian prefect in 260 . Volusianus' rise to the top of the equestrian career had been extraordinarily rapid. ${ }^{148}$ Whether Volusianus accompanied the emperor during the campaigns in the first years of his sole reign is unclear. As said above, he may have stayed in

${ }^{143}$ Though there is little evidence on the centurio deputatus, CIL 6.1110 (Roma) links this centurion to the centurions of the Castra Peregrina. See Dobson (1978), 306. The legion of which Volusianus was centurion is not mentioned.

${ }_{144}$ Dobson (1978), 308. According to Dobson, this position was carried under Philippus Arabs, circa 245.

145 A former tribunus of the Vigiles usually commanded the equites singulares. According to Dobson (1978), 307, Volusianus must have been entrusted with this task temporarily. Dobson adds that whether the appointment was a sign of imperial favor or of a declining significance of these troops cannot be determined, since the circumstances surrounding the appointment are unknown and since there are no parallels for such an appointment.

146 Volusianus was commander, tribunus or praepositus, of detachments of the legions $X$ et XIV Geminarum and the Dacian legion in the Danubian area in the late 240 or 250 . See Pflaum (1960-1961), vol. 2, 901-905, no. 347; Devijver (1976-1990), vol. 2, 639-640, P 30; Dobson (1978), 307.

${ }_{147}$ PLRE I, Volusianus 6, follows Pflaum, (1960-1961), vol. 2, 901-905, no. 347, in dating the tribunates between 255 and 257. Dobson (1978), 308, however, suggests that Volusianus held these commands between 251 and 253, although he admits that these offices may also have been held between 253 and 261. Goltz-Hartmann (2008), 279, note 255, claim that Volusianus received the title protector circa 258. Speidel (2008), 687 , note 90, assumes that Volusianus became protector in 260 , under Gallienus and Saloninus.

${ }^{148}$ Cf. PLRE I, p. 981; Dobson (1978), 307, adds that Volusianus was not primipilus iterum and that he never served as procurator at all. According to Dobson, a rapid rise through equestrian posts was not unusual, if an emperor wanted someone in his entourage to stay put. 
Rome to settle matters there and to deal with potential disturbances in the emperor's absence. It is likely that he continued to be a praetorian prefect until Gallienus left Italy to fight the Goths and Heruli late in the year 266. Then Volusianus became city prefect.

Besides Volusianus, several other protectores are known to us. An inscription from Aquincum (Pannonia Inferior) from 267 refers to a man named (Clementius) Valerius Marcellinus as praefectus legionis II Adiutricis, protector (Augusti nostri) and agens vice legati. Since another man is attested as agens vice praesidis of Pannonia Inferior in those days, Marcellinus was probably acting as vice legati legionis. ${ }^{149}$ Marcellinus apparently survived Gallienus' death. Under Probus, from 277 to 280, he is attested as governor (praeses) of Mauretania Tingitana. ${ }^{150}$

Marcellinus' appointment in Pannonia Inferior parallels that of a certain Publius Aelius Aelianus. Aelius Aelianus was born in Pannonia Inferior as the son of the former custos armorum of legion II Adiutrix and brought up in an army camp near Aquincum. Under Gallienus, he became praefectus legionis II Adiutricis, protector, and agens vice legati in Pannonia Inferior between 260 and 267. ${ }^{151}$ He may thus have been Marcellinus' immediate predecessor. This man is probably identical with the Aelius Aelianus mentioned as praeses of Mauretania Caesariensis in another inscription and may also be identical with the homonymous procurator of Epirus. ${ }^{152}$

${ }^{149}$ CIL $3.3424=$ ILS 545 (Aquincum, Pannonia Inferior). ‘. Clementius Silvius v(ir) e(gregius) a (gens) $v$ (ice) p(raesidis) et Val(erius) Marcellinus praef(ectus) leg(ionis), prot(ector) Aug(usti) n(ostri), a(gens) v(ice) l(egati) .... On Valerius Marcellinus, see $P I R^{2}$ C 1143; PLRE I, Marcellinus 23; Johne-Hartmann-Gerhardt (2008), 1142, with further references. According to PLRE, I, Marcellinus was replaced by Aurelius Frontinus before June 268.

150 See also, $A E$ 1920, $44=I L A f r$ 609; $A E$ 1921, $23=I L A f r$ 610; $A E$ 1916, $92=I L A f r$ 621; CIL 8.21846 (Mauretania Tingitana). De Blois (1976), 46, seems to be mistaken in calling Marcellinus governor of Mauretania Caesariensis.

$151 A E$ 1965, 9 (Pannonia Inferior); CIL 3.3529 (Pannonia Inferior). On Aelius Aelianus, see also PIR A 129; PLRE I, Aelianus $10 \mathrm{cf}$. Aelianus 7 and 8; Pflaum (1960-1961), vol. 2, 948-952, no. 357; Nagy (1965); Goltz-Hartmann (2008), 281, note 260, and JohneHartmann-Gerhardt (2008), 1140, with further references.

152 Aelius Aelianus as praeses of Mauretania Caesariensis: CIL 8, $21486=I L S 4495$ (Mauretania Caesariensis). Aelianus probably governed Mauretania before 277, when Valerius Marcellinus became Mauretania Tingitana's governor. It is noteworthy that the careers of these men are so comparable, as Dobson (1978), 312, has pointed out. Dobson suggests that Aelianus may have been primipilaris, although no source confirms this. Aelius Aelianus as procurator of Epirus: $A E$ 1907, $70=A E$ 1915, $74=I L S$ 9478. The identification of the praefectus legionis with the man mentioned in this inscription was suggested in PIR A 319, but was not accepted by Pflaum (1960-1961), vol. 2, 948-952, 
A man named Marcus Aurelius Victor was procurator and praeses of Mauretania Caesariensis and protector. According to Christol, he was born in Mauretania and returned to the area shortly before the beginning of 263 as procurator, after reaching the rank of primipilaris. As primuspilus and protector, he accompanied the emperor Gallienus during his military service. ${ }^{153}$ This Aurelius Victor has been linked to the Aurelius Victor mentioned in the inscription of the arch of Gallienus in Rome. ${ }^{154}$

Another protector was Traianus Mucianus, whose career is known from an incomplete and heavily damaged inscription from Thracia. ${ }^{155}$ Mucianus presumably started his career as a soldier in a mobile field army of Gallienus, accompanying the emperor during his campaign against the Goths in 267 , after which he became cavalryman in the praetorian guard. The rest of his career suggests that he probably ended up in the corps of evocati. ${ }^{156}$ Mucianus continued his career as centurion, first in legion XIII Gemina, subsequently in cohorts of the Vigiles, an urban cohort, and finally a praetorian cohort. In all cases, the title protector was added. ${ }^{157} \mathrm{Next}$, he was princeps protector/protectorum, but it is unclear in which corps. ${ }^{158}$ The last post which is legible in the inscription is primuspilus (or perhaps primipilaris). The legion concerned is not mentioned, nor is the additional title of protector. ${ }^{159}$ Gallienus' praetorian prefect

no. 357. De Blois (1976), 46, points out that there was another Aelius Aelianus from Photike, who was later v.e. ducenarius ex protectoribus.

${ }^{153} A E$ 1920, 108; $A E$ 1956, 128 (Mauretania Caesariensis). On Aurelius Victor, see PIR ${ }^{2}$ A 1634; PLRE I, Victor 11; Thomasson (1996), 220-221., no. 47; Christol-Salama (2001).

${ }_{154}$ CIL 6.1106 = ILS 548 (Roma). Cf. De Blois (1976), 54; PLRE I, Victor 11.

${ }^{155}$ IGBR 3.2.1570 = AE 1977, 768 (Thracia); on this man's career, see also Christol (1977); Dobson (1978), 313-316, no. 223; Dobson and Breeze (1993).

${ }_{156}$ The evocati were the most competent soldiers of the garrison of Rome who could, after their military service, continue their careers in imperial service in several important positions. In some cases, they could even start a new career as centurion, followed by posts as primipilus, like this Mucianus. See Dobson and Breeze (1993).

157 Christol (1977), 401, note 32 (with further references), mentions a suggestion by Pflaum that Mucianus never actually was centurio vigilum or centurio (cohortis) urbanae, since the inscription does not specifies the cohorts. Christol adds that G. Alföldy describes this as 'eine sehr römische Praxis', especially in times of war.

${ }^{158}$ Domaszweski supplements protectorum. Babut, on the other hand, suggests princeps protector. See Dobson (1978), 314, for references. Cf. Christol (1977), 402-403.

159 The end of Mucianus' career is inscrutable, because the text on the inscription is hardly legible and the Greek terminology is confusing. A reconstruction of the last part of the inscription has yielded the suggestion that Mucianus was praefectus or dux of (probably a vexillatio of) legio IV Flavia, and subsequently praepositus, probably of a field 
Heraclianus, seems to have been Mucianus' patronus. ${ }^{160}$ Perhaps Mucianus was appointed centurio due to Heraclianus' involvement, as Christol suggests. ${ }^{161}$

Based on Mucianus' career, Christol hypothesized that the honorary title protector was assigned to equestrian military cadre officers (centuriones, primipili, tribuni and praefecti) who belonged to the staff of Gallienus' mobile army and who found themselves in the emperor's entourage. Christol furthermore suggests that the title protector was comparable with the title of comes, but that it was used as an alternative term honoring men of lower social standing. ${ }^{162}$

\section{The End of Gallienus' Sole Reign: Goths, Heruli and Assassination $(267 / 268)$}

Table 4.9. Men involved in military events at the end of Gallienus' reign $(267 / 268)$

\begin{tabular}{ll} 
Name & Position \\
\hline Aureolus & $\begin{array}{l}\text { Dux equitum or dux vexillationum in Raetia/in } \\
\text { Germanos? }\end{array}$ \\
Ceronius/Cecropius & Dux (equitum) Dalmatarum \\
Claudius (II Gothicus) & $\begin{array}{l}\text { Dux equitum (or tribunus in Ticinum?) } \\
\text { Domitius Aurelianus }\end{array}$ \\
Dux equitum \\
Heraclianus & $\begin{array}{l}\text { Dux against Vaballathus/Zenobia?? 267? } \\
\text { Praefectus praetorio 267/268 }\end{array}$ \\
Herennius Dexippus & General (dux?) against Goths and Heruli in Athens \\
& $267 / 268$ \\
Marcianus & Dux against Goths $267 / 268$ \\
\hline
\end{tabular}

After a few relatively peaceful years in which Odaenathus defended the East and Gallienus could focus on the enemies on the northern and

army consisting of combined vexillationes of the legions VII Claudia and IV Flavia. See Dobson (1978), 315. Dobson says that these last two posts are usually rendered as $d u x$ and praepositus in Latin, but he stresses that these terms were used to describe several commands of various weight. Mucianus seems to have reached the rank of ducenarius and seems to have become praefectus (of a legion in Mesopotamia?). He is called strategos. Since his career after his position as primipilaris cannot be compared to any other cursus we know, it cannot be supplemented with any certainty, as Dobson (1978), 316, stresses.

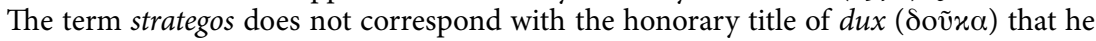
gets in the first line of the inscription.

${ }^{160}$ In 267, Mucianus erected an inscription $(A E$ 1948, $55=I G B R$ 3.2.1569) dedicated to praefectus praetorio Aurelius Heraclianus.

161 Christol (1977), 399-401.

162 Christol (1977), 402-406. 
western borders and the Gallic empire, the year 267 brought more trouble. At the end of that year, Odaenathus and his elder son were assassinated. ${ }^{163}$ Odaenathus was succeeded by his son Vaballathus, who was assisted by his mother Zenobia. Although some late sources implicate Roman involvement, it is hard to see how Gallienus would have profited from Odaenathus' death, and Roman relations with Odaenathus' successors did not change drastically, which renders the suggestion unlikely. Late sources state that Odaenathus assumed imperial power or that he received a general command over the East. Palmyra, however, remained a Roman colonia and there is no real evidence for secessio in the 260 s. ${ }^{164}$ Vaballathus and Zenobia, however, changed their political course and became a threat to Roman authority. ${ }^{165}$

According to the Historia Augusta, Gallienus sent Aurelius Heraclianus, who would later become praetorian prefect, as $d u x$ to settle the situation in the East after Odaenathus' death. ${ }^{166}$ Heraclianus likely had a successful military career before this promotion, in which he took part in Gallienus' wars against barbarian invaders and internal usurpers. Unfortunately, there is no evidence on his early career. Heraclianus was supposed to replace Odaenathus and to take command of the military operations against the Persians. Apparently, however, defeated and his army destroyed by the Palmyrenes under Zenobia, Heraclianus then returned to the West without having achieved his aim. At his return in 267, Heraclianus probably succeeded Volusianus as praefectus praetorio. ${ }^{167}$ No other ancient source refers to this expedition of Heraclianus, and con-

${ }^{163}$ HA, Vita Gall. 13, 1 blames a kinsman; HA, Vita Trig. Tyr. 15, 5-6, 17, 1-3 says a kinsman plotted with Zenobia; Zosimus 1, 39, 2; Syncellus 716-717 (Mosshammer (1984), pp. 466-467); and Zonaras 12, 24, simply refer to a plot, possibly familial. Roman involvement is hinted at by Continuator Dionis, Joh. Antioch., fr. 152, 2, Excerpta de Insidiis 110. On Odaenathus' death, see Hartmann (2008c), 356-357, with further references at note 37 .

${ }^{164}$ Cf. Hekster (2008), 24, who admits that near-contemporary inscriptions call Odaenathus 'restorer of the whole east' or even 'king of kings', but adds that the evidence is posthumous. 'It seems that, though he was de facto ruler of the East, Odaenathus stressed his allegiance to Rome. Gallienus may have held little actual control in Palmyra and its wider surroundings, but Rome could still claim to be its emperor.' Cf. Millar (1993), 170172. Hartmann (2008c), 357, however, assumes that Gallienus was behind the murder.

165 On events in the East just after Odaenathus' death, see Hartmann (2008c), 358-36o, with further references.

166 On Heraclianus as dux, see HA, Vita Gall. 13, 4-5; 14, 1. On Heraclianus, see PLRE I, Heraclianus 6; Johne-Hartmann-Gerhardt (2008), 1073, with further references.

167 According to Goltz-Hartmann (2008), 284, Heraclianus was already praetorian prefect when he was sent against Zenobia. They assume that Heraclianus' campaign in the East was prevented by Aureolus' desertion in 268. 
sidering the reliability of the Historia Augusta, it should be taken into account that it never took place, or at least not during the reign of Gallienus. ${ }^{168}$

In 267/268, Goths and Heruli ('Skythai') invaded the Balkans and seized parts of Moesia and Greece. They devastated large areas in both Thessaly and Greece, including the capture and plunder of most of Athens. As they also threatened the Italic peninsula, the precarious situation asked for Gallienus' immediate attention. Even before the emperor and his armies reached Greece, however, the Athenians themselves acted. The so-called Valerian Wall which surrounded only a small area north of the Acropolis, was created as a last line of defense. ${ }^{169}$ Led by a general named Herennius Dexippus, the Athenians held off the barbarians. ${ }^{170}$ Dexippus came from an important Athenian family and reached the Athenian archonship, although we perhaps know him best as a historian. ${ }^{171}$ Dexippus seems not to have held any Roman offices. Dexippus' family had obviously decided to focus on its status within the Athenian society and thus on their position as local potentes; they did not belong to the Roman senate. ${ }^{172}$ In the battle against the Goths and Heruli, Dexippus excelled as general; he encouraged the Athenian men to fight bravely and to hold on until the imperial fleet arrived. The emperor's fleet came and secured a victory. ${ }^{173}$

Gallienus commissioned a man named Marcianus for his campaign against the Goths. An inscription from Thracia praises Marcianus for saving the city of Philippopolis, presumably from a Gothic attack, and refers

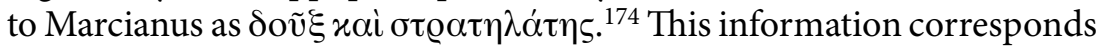
to references in the Historia Augusta, according to which Gallienus

168 Potter (2004), 266, concludes that the expedition to the East did not take place during the reign of Gallienus, as Heraclianus must have been engaged in the Gothic war in 267 , but he suggests that Heraclianus might have made an expedition to the East to restore Roman authority in 270 under Claudius II Gothicus.

169 Millar (2004), 292-293.

170 On Dexippus' defeat of the Goths and Heruli, see HA, Gall. 13, 8; Syncellus 717 (Mosshammer (1984), p. 467). On Dexippus, see also PIR ${ }^{2}$ H 104; PLRE I, Dexippus 2; Goltz-Hartmann (2008), 287, note 275, with further references.

171 On him and his work, see, Millar (1969) and Martin (2006).

172 Cf. Millar (2004), 282-283.

${ }^{173}$ For an account of the battle, see Dexippus, Scythica F28 [F25], translated in Hekster (2008), 115-116.

174 AE 1965, 114. On Marcrianus, see PIR ${ }^{2}$ M 204; PLRE I, Marcianus 2. Gerov (1965) suggests that the title $d u x$ refers to an earlier stage in Marcianus' career-'perhaps service in Pisidia earlier in the reign of Gallienus'. According to PLRE I, Marcianus 2, Marcianus' rank was probably $d u x$, and $\sigma \tau \varrho \alpha \tau \eta \lambda \alpha \dot{\tau} \eta \varsigma$ will be interpretation. 
mobilized Marcianus as dux in his campaign against the Goths in 267 / 268. ${ }^{175}$ Marcianus' early career is not recorded, but must have been mainly military. ${ }^{176}$ He apparently defeated the Goths in Achaia, perhaps in 267 , after which he defeated them again in Illyricum, allegedly aided by Claudius. This future emperor's role in the war against the Goths, however, is dubious and probably aimed at clearing Claudius from any involvement in the conspiracy against Gallienus. ${ }^{177}$ The Goths invaded Asia Minor, but Aureolus prevented any further intervention against them. After Gallienus had left for Italy to put down the revolt of Aureolus, Marcianus was left in control of the war against the Goths. ${ }^{178}$

As has been mentioned above, there is no record of Volusianus' participation in Gallienus' campaign against the Goths and Heruli in 267 / 268. Volusianus was probably promoted to city prefect in Rome when Gallienus left the capital at the end of $266 .{ }^{179}$ Heraclianus took Volusianus' place as praetorian prefect, probably after some successful activities as $d u x$, and accompanied the emperor during the campaign in the Balkan area.

After Raetia had been recovered, Aureolus was stationed there with a mobile cavalry unit. From there, he was able to guard the borders of the Gallic empire, the Danube frontiers of the Empire against Germanic invaders, and the Alpine passes, so that Italy could not be invaded. ${ }^{180}$ In the spring of 268, however, Aureolus turned against Gallienus. He withdrew from Raetia and went to Milan, more or less inviting Pos-

175 HA, Gall. 6, 1; cf. 13, 10; Zosimus 1, 40.

176 This claim is supported by Zosimus 1, 40, who calls Marcianus 'a person of great experience in military affairs.'

177 HA, Claud. 6, 1; 18, 1. Claudius may have remained in the area somewhat longer than Gallienus, but he certainly was in Italy at the beginning of autumn 268, when Gallienus was killed. On the other hand, the reference to Claudius' intervention in this matter supports the assumption that he was a key figure in Illyricum in those days. On Claudius helping Marcianus, see also Goltz-Hartmann (2008), 290, with further references.

178 The precise details on these invasions and the Roman response to it are almost impossible to reconstruct with any certainty as the sources are very confusing. See Potter (2004), 263, and 641-642, note 4, for further references on this matter. According to Gerove (1965), 344, Marcianus was governor of Moesia Inferior and Superior. Against this, see Thomasson (1972-1990), vol. 1, 146, no. 146; 175, no. 165. Cf. Johne-HartmannGerhardt (2008), 1150; 1188, with further references. Marcianus may have been identical to the praeses of Dalmatia in 277, mentioned in CIL 3.8707. See Johne-HartmannGerhardt (2008), 1120.

179 Volusianus as city prefect in 267-268: Chronogr. a. 354; cf. Christol (1986), 130131.

180 Cf. Goltz-Halfmann (2008), 274-275. 
tumus to invade Italy. ${ }^{181}$ Nevertheless, Postumus made no attempts in that direction. Perhaps the soldiers of the Rhine army were dissatisfied because of this lack of action. At the beginning of 269, a usurper named Laelianus, who was probably legatus legionis XXII Primigeniae or governor of Germania Superior, was proclaimed emperor in Moguntiacum (modern Mainz), though he was murdered by his own troops soon thereafter. ${ }^{182}$ Postumus was also killed by his own soldiers in May/June 269. ${ }^{183}$ The Gallic empire still continued to exist until the summer of 274 .

When Postumus did not respond to his invitation and support, Aureolus declared himself emperor at Milan. Two versions exist on Aureolus' exact function at the time he and Gallienus became alienated. Zosimus, followed by Zonaras, claims that Aureolus occupied Milan as commander of the entire cavalry. ${ }^{184}$ Aurelius Victor, on the other hand, does not mention Aureolus' position as commanding officer of the cavalry and reports that Aureolus revolted as leader of the legions in Raetia ('cum per Raetias legionibus praeesset'), as dux exercitus rather than governor. According to Victor, Aureolus subsequently marched towards Italy, where Gallienus defeated him and forced him to withdraw to Milan. ${ }^{185}$ In his article on the reform of the cavalry by Gallienus, Simon finds Aurelius Victor's version more reliable, although he adds that coins attest that Aureolus commanded at least a strong unit of cavalry. He suggests that

181 Aurelius Victor, Liber de Caesaribus 33, 17; Zosimus 1, 40, 1; Zonaras 12, 25. Aureolus issued coins from the mint of Milan in the name of Postumus, probably to elicit the support of the Rhine legions in his struggle against Gallienus. Postumus, however, does not seem to have responded to this, probably refusing to become involved in the venture. On this matter, see Alföldi (1967), 1-15; Drinkwater (1987), 31-33; Watson (1999), 41; Goltz-Hartmann (2008), 288, with further references.

${ }_{182}$ On Ulpius Cornelius Laelianus, see Aurelius Victor, Liber de Caesaribus 33, 8; Eutropius 9, 9, 1. Cf. HA, Vita Tyr. Trig. 5 (calling him Lollianus); Epitome de Caesaribus 32, 4 (where he is called L. Aelianus) and Orosius 7, 22, 11 ('Aemilianus'). See also Kienast (1996), 244-245.

${ }^{183}$ HA, Vita Trig. Tyr. 3, 7; Aurelius Victor, Liber de Caesaribus 33, 9; Eutropius 9, 9.

184 Zos. 1, 40, 1; Zonaras 12, 25.

185 Aurelius Victor, Liber de Caesaribus 33, 17. Zonaras 12, 25, probably also knew this version of the story, since he said that Aureolus revolted while acting as a commander

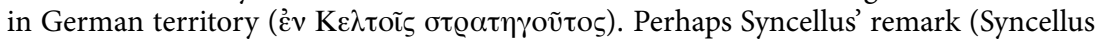

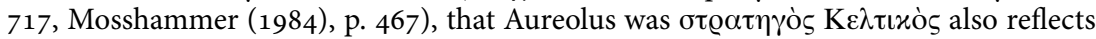
this version. On this, see Simon (1980), 438-439. De Blois (1976), 30-31, asserts that Aureolus was $d u x$ 'per Raetias', based on the words of Aurelius Victor, and he says 'the title could refer to instructions concerning the threat of an attack by the Alemanni on Raetia.' He adds (30, note 34) that 'in addition to the command of the cavalry Aureolus may well have had command of all the troops on the borders between Gallienus' territory and that of Postumus and the Alemanni, as well as of the legions on the Upper Danube.' 
Aureolus' official Latin title may have been dux omnium vexillationum, perhaps with the additional words in Raetia or in Germanos. ${ }^{186}$ Aureolus must have been one of the Empire's most powerful men during Gallienus' reign. Yet he seems to have been the first of Gallienus' generals who showed open dissatisfaction with the latter's regime.

While Gallienus was besieging Aureolus in Milan, he gathered his best men to participate in the battle against his former general. They, however, had other plans. According to several sources, it was the praetorian prefect Heraclianus who instigated the conspiracy against Gallienus. ${ }^{187}$ He probably drew Claudius into the plot. Aurelius Victor reports that, at that time, Claudius was commanding the soldiers stationed at Ticinum, a city close to Milan, as tribunus. Zonaras calls him cavalry commander. ${ }^{188}$ Another possible conspirator was Marcianus. ${ }^{189} \mathrm{~A}$ man named Cecropius or Ceronius, commander of the Dalmatian cavalry (dux Dalmatarum), is mentioned as Gallienus' actual killer. ${ }^{190}$ Two versions of the murder exist. According to the Historia Augusta and Zosimus, Gallienus was told at dinnertime that Aureolus was advancing. He rushed outside to gather his men, but was killed by the commander of the cavalry. Aurelius Victor and Zonaras report that Aureolus had arranged for a forged document in which Gallienus appeared to be plotting against his generals to fall into the hands of Gallienus' senior staff. In this version, Domitius Aurelianus leads the plot. Aurelianus, born during Caracalla's reign in Illyricum, was of humble origins and had a military career which is largely unknown to us. ${ }^{191}$ During the reign of Gallienus, Aurelianus seems to have been cav-

186 Simon (1980), 439-443. At p. 441, Simon adduces mention of Claudius, Aurelianus and Cecropius/Ceronius as leaders of the cavalry as a further demonstration that there was no such thing as one, united cavalry led by one men under Gallienus. Simon furthermore suggests (p. 443) that the Hellenophone authors were probably confused since from the fourth century onward a vexillatio was usually a cavalry unit, whereas the term could refer to a special unit of any kind of troops during the Principate.

187 On Heraclianus' role in the conspiracy: HA, Vita Gall. 14.; Zosimus 1, 40, 2-3.

188 Zosimus 1, 40, 2, posits Claudius' involvement. HA, Vita Gall. 14, 1-9; 15, 2, explicitly exculpates Claudius. Claudius as tribunus: Aurelius Victor, Liber de Caesaribus, 33, 28; as cavalry commander: Zonaras 12, 26.

${ }^{189}$ HA, Vita Gall. 14, 1, 7; however, Zosimus 1, 40, does not name Marcianus as one of the persons involved.

${ }^{190}$ HA, Vita Gall. 14, 4-9. Zosimus 1, 40, 2-3, does not give his name, but describes him as commander of a squadron of Dalmatian cavalry. According to Zonaras 12, 24, Heraclianus was the murderer of Gallienus. PLRE I, Cecropius I, suggests that Cecropius/Ceronius may have been tribunus rather than $d u x$, but this is not explained. Another $d u x$ called Cecropius is mentioned in HA, Vita Prob. 22, 3, as one of the illustrious generals who was trained by Probus, but he may have been fictitious. Cf. PLRE I, Cecropius 2.

${ }^{191} \mathrm{He}$ was born in 214/215 in either Dacia Ripensis or Sirmium. Aurelianus' father 
alry commander (dux equitum). Although it is generally assumed that Aurelianus joined the conspiracy against Gallienus, his exact role cannot be determined. ${ }^{192}$ Aurelianus certainly supported the new emperor Claudius II Gothicus, who eventually promoted him to supreme commander of the whole cavalry of the Roman army and whom Aurelianus even succeeded in the end. ${ }^{93}$

\section{The Aftermath}

After Gallienus had been killed, Marcus Aurelius Claudius (Claudius II Gothicus) succeeded him. Claudius dealt with Aureolus, who surrendered and was killed. ${ }^{194}$ Marcianus allegedly pacified the rebelling troops by bribing them. ${ }^{195}$ Nothing more is heard of Cecropius/Ceronius, but he probably was at least relieved of his post by Claudius and perhaps even executed. Heraclianus committed suicide. ${ }^{196}$ The fate of Volusianus, Gallienus' loyal city prefect, is unknown, but he probably perished not long after the emperor. Claudius ruled the Empire for about two years and was, after a short intermezzo, succeeded by Aurelianus.

allegedly was a colonus (tenant) of a senator named Aurelius, but this may have been invention. HA, Vita Aurel. 3, 1-2; Epitome de Caesaribus 35, 1; Eutropius 9, 13, 1. See Kienast (1996), 234, for further references. The details of his early career as given in $H A$, Vita Aureliani are probably fictitious. On this matter, see PLRE I, Aurelianus 6; Watson (1999), 1.

192 Zonaras 12, 24; Aurelius Victor, Liber de Caesaribus 33, 21, claim that Aurelianus forged the plot. HA, Vita Aurel. 16, 1; Eutropius 9, 11, 1; and Zosimus 1, 40, 1-3, however, do not mention Aurelianus in connection with the conspiracy against Gallienus. On this matter, see Bleckmann (1992), 417; Paschoud (1996), 110. Cf. Goltz-Hartmann (2008), 289-292, esp. 291, note 288, with further references.

193 Aurelianus as supreme commander of the cavalry: HA, Vita Aurel. 18, 1. According to Watson (1999), 42, Aurelianus was immediately assigned Cecropius' former command over the Dalmatian cavalry, and in due course promoted to the position of overall commander of the cavalry, vacated by Claudius himself. 'It may be that Aurelian's complicity in the plot to kill Gallienus was not as incriminating as that of the other two (i.e. Cecropius and Heraclianus), or it may simply be that Claudius knew he could trust Aurelian. In either case, it suggests that Claudius had need of Aurelian, whose popular standing with the army helped to smooth the transition of power. Aurelianus' proclamation: HA, Vita Aurel. 37, 6; Zosimus 1, 47 .

194 On Aureolus: Zosimus 1, 41. On Claudius' proclamation, see also HA, Vita Gall. 15, 3; Claud. 4; Aurelius Victor, Liber de Caesaribus 34, 1; Eutropius 9, 11, 1; Zosimus 1, 41; Zonaras 12, 26.

${ }^{195}$ HA, Vita Gall. 15, 2.

196 Zonaras 12, 25. Heraclianus was probably discarded by Claudius, the new emperor. Or, if Potter's suggestion (Potter, 2004, 266) that Heraclianus was sent on expedition in the east by Claudius and failed to restore Roman authority there is correct, he might have committed suicide after this failure. 


\section{Concluding Observations}

This examination of the men involved in military crises under Gallienus has yielded the following observations regarding power and status in the third-century Roman imperial administrative hierarchies. By 260, imperial authority was highly unstable. Valerianus and Gallienus' joint reign was afflicted by omnipresent incursions of hostile tribes, bringing about discontent among the armies and their leaders. Valerianus' capture must have devastated what was left of the confidence in imperial authority. It presumably was the immediate cause for a number of revolts against Gallienus, which diminished the level of power he exercised. As the emperor faced so many military problems at once in various parts of the Empire, he was highly dependent on his high-ranking military officers to assist him in solving these crises.

Senators' roles in military events seem to have been marginal by the 26os. Although it remains possible that men like Ingenuus, Regalianus and Postumus were senators, the scarcity of information on their social standing is significant. If they were senators, their revolts may have contributed to, or accelerated, the exclusion of senators from military commands. Yet senators' absence at the top of the military hierarchy had obviously started well before in the 240s. Piso and Valens are clearly labeled as senatorial men, but their offices were too unclear and their very existence is doubtful, as no epigraphic attestation confirms the literary sources, so that basing conclusions merely on their cases is thus risky. Only Odaenathus certainly was granted senatorial status. For him senatorial status may have been indispensable, as he combined both military and civil powers in the East, and hence required authority over not only military officers, but also local elites and vassal kings, who may have attached much value to senatorial rank. Equites, however, seem to have exercised more influence in military crises during Gallienus' sole reign, men who had gained relevant military experience and connections with the military middle cadre officers, and who had large numbers of troops and/or supplies at their disposal, many of whom allegedly originated from the Illyrian area.

By the 260 , the military system had become much more flexible. The frontier zones were guarded by long-standing, organized field armies, drawn from the legions and put under the command of generals (duces). Although for most of these men all we have is non-contemporary, literary evidence, which is often confusing and rarely specifies their exact position, the evidence indicates, first, that each of them commanded a 
number of detachments assembled from rearrangements of legions, and, second, that they received these commissions in areas that were threatened continuously by barbarian invasions, like Illyricum and Gallia. In such areas, these high-ranking officers either replaced the governors, or at least assumed the governors' military responsibilities. Since structural military emergencies were inflicting the Empire in those days, this system became more or less permanent. This system, however, depended greatly on commanders' acceptance of imperial authority, as attempts by several of these duces to seize imperial power proved. Yet, as their power was primarily based on regional connections and support of the armies under their command, their claim for power often received acceptance only at the local level.

To fight these usurpers and to solve other temporary local crises, Gallienus mobilized field armies under the command of troubleshooting generals, such as Aureolus, who are often called dux equitum, cavalry commander, in the literary sources. These generals certainly seem to have commanded mobile detachments, since they show up in geographically disparate areas of the Empire successively to solve crises. Yet it would be rather strange if they only had cavalry units at their disposal. Although the importance of the cavalry had risen steadily from mid-second century onward, infantry remained a relevant military instrument as well. It may be true, however, that a large cavalry corps was the core of Gallienus' mobile field armies. ${ }^{197}$ We should note that we are perhaps dealing with an anachronism here, since vexillatio, which originally meant 'detachment of one or several legions', came to mean 'cavalry unit' in Late Antiquity. ${ }^{198}$ Hence, these troubleshooting generals may have been duces vexillationum, a title by which late Roman and Byzantine authors eventually designated cavalry commanders. Gallienus' mobile detachments probably foreshadowed the rise of comitatenses in the Late Roman Empire.

The increasing importance of the professional staff of high-ranking officers and subaltern officers appears from the special corps of protectores, which developed in the mid-third century. Commanders of army corps and vexillationes were appointed from this group. By giving

197 Cf. Strobel (2007), 276, who regards the cavalry under Gallienus as an elite corps, based on the role cavalry commanders and the equites Dalmatae played in Gallienus' murder.

198 According to Strobel (2007), 268, the term vexillatio was already used in AD 293 to denote cavalry units as opposed to the infantry legion. 
professional officers the title protector, Gallienus tightened the bonds between himself and these officers. The (equestrian) protectores may have largely replaced the (senatorial) comites as military advisers. If the title protector was indeed most commonly used for officers in the emperor's entourage, emperors may have granted this honorary title to their staff as a direct appeal for loyalty.

Gallienus also depended on what we may refer to as local strongmen. On the one hand, these were local men who took their own initiatives in defending an area which belonged to the Roman Empire. Whereas Dexippus' action in Athens was a once-only occurrence, Odaenathus' assistance in the East became more structural. On the other hand, Gallienus tried to overcome his problems in border areas by making treaties with local kings and leaders from outside the Empire, allowing them to settle on Roman territory while outsourcing the defense of parts of the frontier regions to them.

To conclude, senators' level of military power under Gallienus was low. They had lost their position to equites, as by then they lacked military experience and did not have the appropriate connections. Connections with other senators and members of the senatorial elite were no longer relevant; relations with the equestrian military middle cadre were. While the power of the equites as a whole grew, individuals' power remained restricted, as the emperor divided military responsibilities among a large number of men, who each received a small concentration of power over detachments of legions in the Empire's periphery. Even the duces of the more flexible, mobile field armies remained unable to challenge the emperors' power for long. When all of them assembled in Milan, they were able to link up and actually threaten imperial power. Ironically, Gallienus' sole reign thus ended where it had begun, in Milan, where men from the periphery who had assembled in the center of the Empire killed the emperor.

\subsection{Conclusion}

Now that we have both defined the military set under Severus and Gallienus and discussed how each emperor dealt with them, it is time to make up a balance. How do these cases compare? Which developments can be drawn and how can these be accounted for? 


\section{Acting or Reacting: Changing Times, Changing Attitudes}

First of all, we need to take into account that the reigns of Septimius Severus and Gallienus differed fundamentally in the proportion of the reign that was taken up by military conflicts and, consequently, in the role played by military officers during these reigns. Whereas Severus confronted military conflicts only at the beginning and the end of his reign, Gallienus' rule was continuously afflicted by military incidents. Gallienus' sole reign may have experienced relative peace between 262 and 267, but no phase of absolute peace as Severus had experienced between 198 and 208. Consequently, Severus did not depend so completely on his military officers during his entire reign. Also reducing Severus' dependence on his military officers were the temporally successive and geographically confined nature of his military engagements, whereas Gallienus dealt with simultaneous and geographically disconnected threats. Finally, perhaps the most crucial difference was that most of Severus' external conflicts, the emperor had initiated himself: although the expedition against the Parthian vassal kings and the campaign in Britannia were responses to previous events in those areas, intervention was not inevitable in either, since the frontier areas of the Empire had not, or at least not yet, been invaded. By the time Gallienus was sole ruler, the emperor was no longer initiating military conflicts; he could only react to the events which others initiated. That is why Gallienus had to depend on his military officers throughout his entire sole reign, much more than Severus had. Both Gallienus' officers and the inhabitants of the Empire must have realized this, and it is clear that their expectation that the emperor would solve every situation decreased. So did their loyalty to imperial authority.

\section{The Social Rank of the Military Officers}

A second distinction between the situation at the end of the second century and the situation in the 26 os relates to the social rank of highranking military officers. The military officers under Severus can be roughly divided into four groups. First are senatorial viri consulares, who governed imperial provinces as legati Augusti pro praetore and in that capacity held the supreme command over the legions stationed in their provinces. Governors of provinces with two or three legions would have many troops at their disposal and, consequently, possessed considerable military power. This situation could pose an immediate threat to imperial authority, as it provided senators with the means (money and 
troops) to seize imperial power. The second group consisted of generals, who were commissioned by the emperor as troubleshooters in times of military crises. They were assigned to special army detachments drawn from the legions for a particular military expedition. If successful, a general and his field army could be mobilized in other campaigns as well. Many of Severus' generals were of senatorial rank, a mix of born senators and homines novi. A third group consisted of senators who were deployed as advisers (comites) and served in the imperial entourage during campaigns. Even if these senators had little or no military experience, they could nonetheless contribute valuably to the campaign. Their wealth, status and influence (particularly in Rome) and of course their connections with other senators helped Severus strengthen his position, which the emperor obviously considered necessary at the beginning of his career. To the fourth group belonged lower commanders, primarily of equestrian status, subordinated to the senatorial generals (duces).

A prosopographical examination of the military officers in the $260 \mathrm{~s}$ makes clear that the role of senators in military affairs had by then heavily decreased. It is quite obvious that under Gallienus, the old system, in which provincial governors had held ultimate military commands unless a military crisis demanded drastic interference of a $d u x$ with a special task, could no longer be preserved: structural military problems in several border areas required more permanent solutions. Some areas, such as Illyricum, were almost continuously guarded by army detachments led by generals, who should not be-but often are-confused with provincial governors. Moreover, to fight usurpers and solve other temporary local crises Gallienus mobilized field armies under the command of troubleshooting generals, who are often referred to as dux equitum. Gallienus' generals seem mostly to have been men who had emerged from the military cadre, with substantial military experience and connections and who had reached equestrian rank. The role of senators as imperial advisers during campaigns seems to have become minimal as well. Useful connections no longer compensated for senators' lack of military experience, so the emperor no longer needed to take them along during expeditions. As they were no longer useful and could perhaps even burden the army amid harsh campaigns, their place was probably largely taken by equites who combined military expertise with useful connections within the armies and familiarity with the war zones. Since most men attested as protectores belonged to this group, the suggestion that protectores largely replaced the comites as military advisers is plausible. 
Consequently, while military capability became ever more relevant because of the increasing number of military threats, senatorial status was no longer a goal for military officers. The practice of elevating successful equites to senatorial rank, to appoint them subsequently to senatorial posts, was no longer common by the 260 . So by the sole reign of Gallienus equestrian officers were no longer included in the senatorial class and senators were no longer officers. As a consequence, senatorial support seems to have become less urgent for the emperor. Thus, in areas dominated by warfare, military power and senatorial status drifted further and further apart.

\section{Strategies to Secure Imperial Power}

Yet besides these circumstances and their uncontrollable consequences, both Severus and Gallienus made strategic arrangements in an attempt to prevent the military from becoming too great a threat to imperial power.

Severus created good relations with the soldiers by giving them donatives, increasing their pay by half and by giving them other benefits, like allowing them to marry while in service. The praetorians were dismissed and a new guard, twice as large, was created out of provincial soldiers, mostly from the Danubian legions that had supported the emperor from the start. The urban cohorts and the Vigiles in Rome were increased too, while three new legions were raised, two of which were sent to the eastern border regions, the third being based in central Italy. All his military reforms were expensive, but they must have increased the soldiers' loyalty towards the Severan dynasty. ${ }^{199}$ Moreover, Severus used every chance to involve his entire family in the army: Iulia Domna was granted the title mater castrorum, and Caracalla and Geta were actively involved in the campaign in Britannia. ${ }^{200}$ Severus' reliance upon the military is best reflected in the advice he is said to have given his sons in his famous last words: 'Be harmonious, enrich the soldiers, and scorn all other men.'201

199 On the donatives and soldiers' new priviliges, see Herodianus $2,11,1 ; 2,14,5 ; 3$, 6,$8 ; 3,8,4-5 ;$ HA, Vita Sev. 5, 2; 7, 6-7; 12, 2; 16, 5-9. On the army's pay raises, see Develin (1971); Speidel (1992); Alston (1994), 114-115; 118. On soldiers' right to marry, see Pfang (2001). On Severus' measures generally, see also Birley (1988), 102-103, with further references. Severus' military successes were celebrated on his arch in the Forum Romanum.

200 On Iulia Domna as mater castrorum, see Birley (1988), 115-117, with further references.

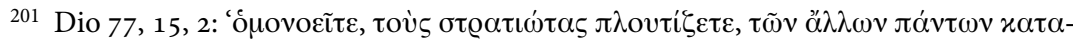

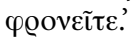


Severus' behavior toward high-ranking military officers, however, was equivocal. Although he sought senatorial support at the beginning of his career, Severus does not seem to have trusted his senatorial generals entirely, as he continually avoided appointing them to positions of great military power. Especially those born into the senatorial order were only sporadically sent to lead in military events and then transferred to positions of a more civil-administrative nature. In that way, Severus made sure that those men whose status gave them easy access to money and senatorial support were not given too many troops. Homines novi were put into action more often, but after the civil and Parthian wars had ended, most of them disappear from view, temporarily or permanently. None of them received high military commands in times of war again, not even for Severus' campaign in Britannia.

By the time Gallienus became sole emperor, it was quite obvious that the men who could undermine the emperor's position were no longer primarily senators. By then, senators were only rarely appointed to offices which provided them with the military power necessary to prepare a coup. Instead, from the late 230 s onward, these posts went into the hands mostly of equestrian men, many of whom came from the military middle cadre. These equestrian generals had at their disposal the means that senatorial consular governors had had at the beginning of the third century: troops and relevant connections. The case of Laetus demonstrates that Severus had also considered generals who gained too much popularity among their troops as threats to his power. Unlike Gallienus, however, Severus was able to dispose of this general when he reached a point in his reign where he no longer depended on his military officers. Gallienus' reign never saw such a peaceful period, and Gallienus' generals must have been aware of their powerful position. The events in $260-262$ demonstrate that by then even men of lower social standing could threaten imperial authority. Gallienus took multiple measures in an attempt to prevent the military from becoming too great a threat: he strengthened the ties between his officers and himself, he reduced his officers' power and he enlarged his own control over military affairs. Furthermore, he realized that he needed a more flexible military defense system to accomplish these goals, and to cope concurrently with the problems afflicting various quarters of the Empire during his reign.

A considerable number of duces emerged under Gallienus. They commanded either long-standing field armies in frontier zones or more flexible, mobile detachments. A large cavalry corps seems to have formed 
the core of these army units. ${ }^{202}$ Nowadays it is debated whether Gallienus actually composed an entirely new mobile field army consisting of (mainly) cavalrymen, but it is clear that a more flexible system with a higher proportion of mobile army units that was applied for specific purposes, had came into use by the 260 . These mobile army units were necessary for actions in various areas of the Empire with the most suitable troops.

By dividing military responsibilities among a larger number of generals, each with a particular task or region, who were all directly accountable to the emperor, the ruler could supervise them more strictly than before. Further promoting his control was the emperor's more active personal participation in military affairs, which had developed between the beginning of the century and mid-third century. Whereas Severus had restricted his role in his expeditions, Gallienus dealt with many military crisis situations himself, as Valerianus had done in the East.

A special corps for the professional higher staff of officers and subaltern officers had emerged mid-third century: the protectores. Commanders of army corps and vexillationes were appointed out of this corps. By granting professional officers the title protector, Gallienus tightened the bonds between himself and this officers further. If the title protector was indeed most commonly used for officers in the emperor's entourage, it may be considered a direct appeal for loyalty expressed by the emperor, addressed to his general staff.

Besides these measures, Gallienus also depended on what we may call local strongmen, both Romans who took their own initiative and non-Roman local kings, who were allowed to settle on Roman territory as long as they defended the border regions against other tribes. The latter practice in itself was not new: previous emperors had made peace agreements with vassal kings. Parthian kings, for instance, had backed Niger in his battle for the throne and incurred punishment for this from Severus. Only the proliferation and extent of these treaties were new. According to some scholars, these barbarians were even deployed as mobile elite forces.

With all these measures, Gallienus tried to overcome the numerous problems he faced, and even though his reign was far from peaceful, he managed to reign for fifteen years. Hence, it is reasonable to

202 Strobel (2007), 276, regards the cavalry under Gallienus as an elite corps, based on the role cavalry commanders and the equites Dalmatiae played in the murder of Gallienus. 
conclude that his measures, or at least some of them, succeeded, which also appears from the fact that Diocletian adopted several of them in his reforms.

In conclusion, a comparison of the high-ranking military officers under Severus and Gallienus not only illustrates the increasing chaos in the third century, which is reflected in the available sources; it also reveals two main developments which were detected throughout the previous chapters: (1) the rise of equites as leading men in military crises, and (2) a widening gulf between military power and senatorial status in the military context. These developments are represented in the careers of a number of individuals involved in military events between the reigns of Severus and Gallienus, who have been discussed regularly throughout this study, for example Macrinus, Oclatinius Adventus, Timesitheus, Maximinus Thrax and Priscus. Whether there actually was an official edict or not, Gallienus seems to have confirmed a situation which had gradually become the status quo: senators were excluded from military commands. These measures probably did not come as a shock to the senators whose reluctance to pursue dangerous duties in the army must have increased in those unsettled times. The division between civil and military careers, which had started under Marcus Aurelius, had become entrenched under Gallienus. It was only a fairly small step for Diocletian to institutionalize this division. 